\title{
Too Little, Too Late: Ineffective Assistance of Counsel, the Duty to Investigate, and Pretrial Discovery in Criminal Cases
}

Jenny M. Roberts

American University Washington College of Law, jenny@american.edu

Follow this and additional works at: https://digitalcommons.wcl.american.edu/facsch_lawrev

Part of the Criminal Law Commons, and the Criminal Procedure Commons

\section{Recommended Citation}

Roberts, Jenny M., "Too Little, Too Late: Ineffective Assistance of Counsel, the Duty to Investigate, and Pretrial Discovery in Criminal Cases" (2004). Articles in Law Reviews \& Other Academic Journals. 1746. https://digitalcommons.wcl.american.edu/facsch_lawrev/1746

This Article is brought to you for free and open access by the Scholarship \& Research at Digital Commons @ American University Washington College of Law. It has been accepted for inclusion in Articles in Law Reviews \& Other Academic Journals by an authorized administrator of Digital Commons @ American University Washington College of Law. For more information, please contact kclay@wcl.american.edu. 


\title{
TOO LITTLE, TOO LATE: INEFFECTIVE ASSISTANCE OF COUNSEL, THE DUTY TO INVESTIGATE, AND PRETRIAL DISCOVERY IN CRIMINAL CASES
}

\author{
Jenny Roberts*
}

Where money is involved, all parties receive all relevant information from their adversaries upon request; but where individual liberty is at stake, such information can be either withheld by the prosecutor or parceled out at a time when it produces the least benefit to the accused. ${ }^{1}$

\section{INTRODUCTION}

You are an attorney for the Criminal Defense Division of the Legal Aid Society in Manhattan, and you go into Criminal Court to work an arraignment shift. The folder with your next client's case-her name is "Jane Smith"2 _ contains only one piece of paper related to the charge: the Criminal Court Complaint. It lists the charge of Grand Larceny and offers only the following facts: that at around 1:00 p.m. on August 1, 2003, near the corner of Third Avenue and Twenty-third Street, "a person known to the District Attorney's office" informed the police that "Jane Smith did steal $\$ 3,500$ " from her. Your client has little information to add because she is innocent. She has no idea what this is about. She only vaguely remembers where she might have been at the time, as

* Acting Assistant Professor of Law, New York University School of Law. I am grateful to the Lawyering Program faculty at NYU, and in particular to Mary Holland, Babe Howell, and Juliet Stumpf for their support and very helpful comments. I also benefited greatly from comments from Rachel Barkow, Adele Bernhard, Jerome Bruner, Jerome Cohen, Peggy Davis, Randy Hertz, Jim Jacobs, Youngjae Lee, Holly Maguigan, Jerry Skolnick, and the NYU criminal law lunch group members. Rachel Lerner and particularly Lauren Cusick provided invaluable research assistance. A special thanks to Andrew Benepe for his support as I worked on this article.

1. Hon. H. Lee Sarokin \& William E. Zuckerman, Presumed Innocent? Restrictions on Criminal Discovery in Federal Court Belie This Presumption, 43 Rutgers L. REV. 1089, 1089 (1991).

2. This case is based loosely on a real case from my past practice as a Staff Attorney at the Legal Aid Society, Criminal Defense Division, New York County. All names have been changed. See infra text accompanying notes 149-192 for a full discussion of Jane Smith's case. 
the date was more than three months ago. And that one piece of paper, which does not give you the name of the complaining witness, is almost all of the information you will get in this case until seven months later on the morning the trial begins. It is all the information you receive because the statute governing discovery in New York State is highly restrictive and requires little disclosure of information meaningful to the ability to investigate until it is too late. For example, discovery that is as central as police reports containing statements of trial witnesses is mandated only after the jury is sworn. ${ }^{3}$

Unlike rules governing discovery in civil cases, which require that the two sides exchange most information about their respective cases, ${ }^{4}$ criminal discovery result in a much more limited flow of information. Many commentators, for many years, have called for the liberalization of criminal discovery statutes and rules. ${ }^{5}$ Indeed, some states have heeded the call. Florida allows defense counsel to depose prosecution witnesses; ${ }^{6}$ New Jersey has long had broad

3. N.Y. Crim. Proc. Law $\$ 240.45$ (McKinney 2002). To illustrate the difficulties defendants face under the restrictive federal discovery rules, Sarokin and Zuckerman offer the following excerpt of defense counsel's pretrial argument:

I would like to put it in context for the court very briefly. From what I know about the case, and what I don't know because I think it would help you evaluate our request for a bill of particulars, this is a situation where my client was not arrested in possession of anything, no search [was] conducted of his car which produced any evidence.

As far as I know, there is no electronic surveillance or other surveillance. I have been given nothing specific at all. I have a charge that says in or about October of ' 88 , which doesn't limit it to the month of October, he allegedly possessed some methamphetamine with intent to distribute. Not told where or with whom or under what circumstances. . .

My client is presumed innocent. The Government shouldn't be saying that the defendant since he must be guilty must know what he is accused of doing. I have no idea what he is accused of doing, and he doesn't know what kinds of proofs the Government intends to offer. I think under the circumstances we should be given more.

Sarokin \& Zuckerman, supra note 1, at 1092-93, 1095 (citing district court proceedings).

4. See, e.g., FED. R. Civ. P. 26.

5. See, e.g., William J. Brennan, Jr., Criminal Prosecution: Sporting Event or Quest For Truth?, 1963 W AsH. U. L.Q. 279 (1963) [hereinafter 1963 Brennan]; William J. Brennan, Jr., Criminal Prosecution: Sporting Event or Quest For Truth? A Progress Report,, 68 WASH. U. L.Q. 1 (1990) [hereinafter 1990 Brennan]; Sarokin \& Zuckerman, supra note 1, at 1089 (noting that "[i]t is an astonishing anomaly that in federal courts virtually unrestricted discovery is granted in civil cases, whereas discovery is severely limited in criminal matters"); Roger J. Traynor, Ground Lost \& Found in Criminal Discovery, 39 N.Y.U. L. REv. 228 (1964).

6. Fla. R. CRIM. Proc. 3.220(h)(1)(A) (2003). 
discovery rules. ${ }^{7}$ Around one-third of the states have relatively broad discovery rules or statutes, modeled on American Bar Association standards. ${ }^{8}$ But about a dozen states follow the highly restrictive federal rule, which is premised in part on the idea that a defendant should not be entitled to witness names or statements for pretrial investigation, but rather only for cross-examination purposes should the case ever get to that stage. ${ }^{9}$ The remaining states fall between the two models. ${ }^{10}$

New York is on the restrictive end of the spectrum. As Smith's attorney, you need to investigate the case; indeed, you are aware that you have a constitutional duty to do so. ${ }^{11}$ But just about all you can do, with the limited information you have, is to visit a vaguely-defined crime scene in a very busy area of Manhattan. This is your situation right up until the start of the trial.

Jane Smith has a right, under the Sixth Amendment, to the "effective assistance of counsel." 12 Investigation of the prosecution's case and possible defenses has long been recognized as a core function of defense counsel in a criminal case, one that is necessary to the testing of the facts in our adversarial system. ${ }^{13}$ This function has been consitutionalized as the Sixth Amendment duty to "make reasonable investigations or to make a reasonable decision that makes particular investigations unnecessary." "Yet does the representation of Jane Smith ensure an adversarial testing of the facts so as to protect against conviction of the innocent even while convicting the guilty? Is the quantum of investigation that the discovery rules allow defensible under the constitutional principle that

7. N.J. CT. R. 3:13-3(c)(6) (2003).

8. Wayne R. LaFave et al., Criminal Procedure \$20.2(b), at 916 (3d ed. 2000); see also Am. Bar Ass'N Project on Standards for Criminal Justice, Standards Relating to Discovery and Procedure Before Trial 1 (approved draft, 1970) [hereinafter Standards Relating to Discovery].

9. See LAFAve, supra note $8, \$ 20.2$ (b), at 916; see also FED. R. CRIM. P. 16 (relaying discovery rules for criminal cases and noting that discovery of government witness statements is governed by 18 U.S.C. $\$ 3500$ ); see also 18 U.S.C. $\$ 3500$ (a) (2000) (stating that the recorded statement of a government witness must be provided to a defendant only after the witness has testified on direct examination at trial).

10. LAFAVE, supra note $8, \S 20.2(\mathrm{~b})$, at 916.

11. See infra Part II.A discussing the duty to investigate.

12. McMann v. Richardson, 397 U.S. 759,771 n.14 (1970) (stating that "[i]t has long been recognized that the right to counsel is the right to the effective assistance of counsel"); see also U.S. ConsT. amend. VI.

13. See infra text accompanying notes $28-61 \& 106$.

14. Strickland v. Washington, 466 U.S. 668, 691 (1984) (establishing two-prong test to make a claim of ineffective assistance of counsel under the Sixth Amendment). In this article, "duty to investigate" means the standard as enunciated in Strickland. 
adversarial testing cannot take place without defense counsel's independent investigation of the facts? The right to effective assistance of counsel rings hollow when restrictive discovery rules render an attorney unable to investigate the facts of the case.

There are clear connections among the effective assistance of counsel, the duty to investigate and discovery. It is the aim of this article to both explore those connections and to urge a Sixth Amendment analysis of restrictive discovery rules. This article describes how restrictive discovery rules block the delivery of effective assistance of counsel when defense counsel has insufficient information to investigate the case. The Supreme Court has not undertaken this type of analysis; it has considered discovery almost exclusively through the lens of due process under the Fourteenth Amendment. ${ }^{15}$ Scholarship on discovery also largely fails to explore the validity of restrictive discovery under such a Sixth Amendment analysis. ${ }^{16}$

15. See, e.g., Brady v. Maryland, 373 U.S. 83, 87 (1963); see also infra Part III.B.

16. See, e.g., Sarokin \& Zuckerman, supra note 1. Judge Sarokin and William Zuckerman recognize that "[t]he failure to provide full disclosure of the government's case early in the proceedings limits a defendant's ability to investigate the background and character of government witnesses and the veracity of their testimony." Id. at 1090. Noting that discovery restrictions "impinge upon the right of defendants to a fair trial," id., the authors claim that liberalization of discovery is a "task for the legislature," and give only brief attention to the potential constitutional bases for an expanded right to discovery. $I d$. at 1108 . They state simply that "[t]he call for a constitutional right of discovery is compatible with the holding in Brady," and note that "the fact that many prosecutors choose to open their files to opposing counsel raises the additional issue of equal protection." Id. at 1107 . Similarly, Justice Brennan acknowledged the need for broad discovery for defendants for investigatory purposes, but did not link that need to the constitutional right to effective assistance. See 1990 Brennan, supra note 5. Justice Brennan claimed that the American Bar Association's Standards for Criminal Justice, which recommended a rule of open file discovery, stated the "bare minimum of discovery that should be required." Id. at 11 . He noted that such standards would "certainly improve a defendant's opportunity to investigate evidence, to interview witnesses, and in general to prepare for trial," and in fact claimed that even broader discovery was necessary to allow for adequate investigation in several specific areas. Id. at 12 . He never articulated, however, a constitutional basis for his claims, noting only generally that " $[\mathrm{t}]$ he proper guide to discovery practices should not be the likelihood that disclosure in a particular case will save the trouble of a trial, ... but the degree to which discovery will enhance the reliability of factfinding." Id. at 2-3.

Some of the literature notes, but does not closely examine, the connection between discovery and the right to effective assistance of counsel. See, e.g., Cary Clennon, Pretrial Discovery of $W$ Lists: A Modest Proposal to Improve the Administration of Criminal Justice in the Superior Court of the District of Columbia, 38 CATH. U. L. REv. 641, 668-74 (1989) (discussing the relationship between pre-plea discovery and the effective assistance of counsel on a practical level but noting that "discovery itself is not even a constitutional right"); Ellen S. Podgor, Criminal Discovery of Jencks Witness Statements: Timing Makes a Difference, 15 GA. ST. U.L. REv. 651, 695 (1999) 
Reconsideration of the discovery framework is timely for two reasons. First, the Supreme Court has given much more vigor to defense counsel's Sixth-Amendment-based duty to investigate in two recent decisions which reversed death sentences: Williams $v$. Taylor, ${ }^{17}$ in which, for the first time, the Supreme Court found ineffective assistance of counsel based on defense counsel's inadequate investigation, ${ }^{18}$ and Wiggins $v$. Smith.$^{19}$ In its 2003 decision in Wiggins, the Supreme Court found that defense counsel's paltry investigation into mitigation evidence for Wiggins's capital sentencing hearing did not comport with "prevailing professional norms."20

(noting ABA Rules of Professional Conduct and Standards for Criminal Justice in stating that "defense counsel is at a serious disadvantage in performing his or her role as an effective advocate when information for trial preparation is not provided or delayed" (footnotes omitted)); see also Linda S. Eads, Adjudication By Ambush: Federal Prosecutors' Use of Nonscientific Experts in a System of Limited Criminal Discovery, 67 N.C. L. REv. 577 (1989). Eads, in the context of critiquing the federal rules that inhibit discovery of nonscientific expert materials, undertakes a brief survey of potential constitutional bases for challenges to the federal discovery rules as they relate to nonscientific expert witnesses. Id. at 612-21. Eads briefly lists two potential arguments for broader discovery under the Sixth Amendment right to effective assistance. Id. at 617-18. She concludes, however, that such claims would be hard to win, that they could be made only in a limited number of cases, and that "[s]uch an expansion of constitutional rights into the area of criminal discovery has implications for the entire criminal justice system that may not be in the best interest of society as a whole." Id. at 618. The focus of Eads' article is thus on addressing "the deficiencies in the procedural rules themselves rather than [on arguing] to expand constitutional protections into the area of criminal discovery generally." Id.

The notable exception is Anthony Amsterdam's reporting in 2 Trial Manual 5 For the Defense of Criminal Cases (1989 ed.) [hereinafter Trial Manual 5], where he leads off the section on constitutional concerns relating to discovery with the Sixth Amendment right to counsel. Id. $\S 270$. In the manual, Amsterdam argues that right-to-counsel claims could be based on defense counsel's inability to prepare adequately for a case without pretrial discovery. Id. This argument is developed only briefly and was articulated prior to recent Supreme Court decisions on the duty to investigate. See infra text accompanying notes 58-62 and Part II.B. Still, the argument is the core claim of this article-that a right-to-counsel analysis should inform constitutional claims about discovery.

17. 529 U.S. 362 (2000).

18. Id. at 371 .

19. 123 S. Ct. 2527 (2003). Coming three years after the decision in Williams $v$. Taylor, the Wiggins Court also granted the defendant's claim of ineffective assistance based on investigatory failures. Id. at 2536-37; see also Supreme Court 2002 Term, Leading Cases, 117 HARv. L. Rev. 278, 278 (2003) [hereinafter Leading Cases] (noting that "[a]fter nearly twenty years," the standard governing claims of ineffective assistance of counsel that was announced in "Strickland v. Washington has finally been given teeth").

20. Wiggins, $123 \mathrm{~S}$. Ct. at 2535. Both Williams and Wiggins address failures to investigate mitigation evidence at a capital sentence hearing. The constitutional principles articulated in the cases, however, apply equally to investigation at the guilt/ innocence phase in non-capital cases. See infra text accompanying notes 107-09. 
The trial attorneys in Wiggins had the tools at their disposal to do the necessary investigation; records in their possession suggested a very troubled childhood. They simply failed to investigate this avenue. $^{21}$

In many cases, such as that of Jane Smith, defense counsel do not have the tools to investigate the facts because their clients cannot give them the information they need to begin an investigation. This situation is presented most starkly with an innocent defendant, who knows nothing about the facts of the case against him and thus has no information to share. ${ }^{22}$ How can counsel investigate enough to make informed choices about trial defenses when the client can say no more than "I know nothing about these charges"? The assumption that the defendant has enough information about the case to allow for investigation flies in the face of the constitutional right to a presumption of innocence. ${ }^{23}$

While the problem of acquiring adequate information for investigation in the case of an innocent defendant presents a compelling example that resonates with our notions of fundamental fairness in the adversary system, the problem exists well outside of the innocence context. Assuming that defense counsel can garner all necessary information from her client ignores the fact that many defendants suffer from mental illness or retardation, drug or alcohol abuse, impaired memory, and other impediments which might prevent them from being an adequate, sole source for investigative

21. In Wiggins, the attorneys not only had the information at their disposal, they also had the means to use the information, as their office had funds to hire an expert to prepare a social history of Wiggins. $I d$. at 2536 . In some cases, the attorneys have the information at their disposal but cannot make use of it due to caseload pressure, lack of resources, and other systemic obstacles. As noted infra note 111 and accompanying text, recognizing such systemic problems, this article focuses on the stage of obtaining information in situations where defense counsel does not have enough to undertake adequate investigation.

22. While defendants may learn some of the facts of the case from the arresting officer or other law enforcement officials during the arrest process, such information would rarely, if ever, rise to the level of specificity necessary for investigation. In addition, since law enforcement can and does lie to defendants in the course of interrogation, it would be difficult for defense counsel to know what information she could rely on from such a source.

23. See Apprendi v. New Jersey, 530 U.S. 466, $477-78$ (2000) (explaining that "[t]aken together, ... [Fourteenth and Fifth Amendment] rights indisputably entitle a criminal defendant to a jury determination that [he] is guilty of every element of the crime with which he is charged, beyond a reasonable doubt" (internal quotation omitted)); see also 1963 Brennan, supra note 5 at 287 (questioning "does not the denial of all discovery set aside the presumption of innocence-is not such denial blind to the superlatively important public interest in the acquittal of the innocent?"). 
leads. ${ }^{24}$ It also assumes that the defendant (even one who is guilty) possesses specific information, such as names and addresses of potential witnesses, which is necessary for defense counsel to adequately investigate the case. It ignores the fact that incarcerated defendants cannot bring their attorneys to relevant people or places when they lack this information, and instead, perhaps only know someone by nickname or by sight. Certainly, attorneys faced with these obstacles must also investigate the case in order to fulfill the promise of effective assistance under the Sixth Amendment, be that in a trial or in appropriately counseling a client in the context of a plea bargain. ${ }^{25}$ The right to effective assistance is not contingent upon innocence. ${ }^{26}$

The second reason that reconsideration of the analytic framework for discovery is timely is that the recent debate over fairness in the death penalty has led to a greater understanding of the causes of wrongful convictions and to the identification of inadequate investigation as a core cause. This is perhaps the driving force behind the Court's renewed attention, in Williams and Wiggins, to failures to investigate. If adequate investigation can help protect against wrongful conviction, then courts must give the constitutional duty to investigate real meaning by giving defense counsel the discovery they need in order to investigate.

The role that discovery can play in advancing the goals of thorough investigation has not received the attention it deserves: as a mechanism to advance full airing of well-developed facts in an adversarial proceeding or within a plea bargain process where each side investigates enough so that there is some adversarial testing. While discovery that is broad enough and early enough in the case

24. See, e.g., Atkins v. Virginia, 536 U.S. 304, 320 (2002) (acknowledging that "[m]entally retarded defendants may be less able to give meaningful assistance to their counsel"); United States v. Renfroe, 825 F.2d 763, 767 (3d Cir. 1987) (describing doctor's testimony, with respect to defendant who abused cocaine for sixteen years prior to as well as during his trial, "that cocaine addiction would affect a defendant's capacity to confer effectively with counsel"); Melinda G. Schmidt et al., Effectiveness of Participation as a Defendant: The Attorney-Juvenile Client Relationship, 21 BEHAV. SCI. \& L. 175 (2003).

25. See Impact of Problem Solving on the Lawyer's Role and Ethics, 29 Fordham URB. L.J. 1892, 1919 (2002) (discussing lawyer's duty to investigate before counseling client regarding a plea). See generally Steven Zeidman, To Plead or Not to Plead: Effective Assistance \& Client-Centered Counseling, 39 B.C. L. Rev. 841 (1998).

26. See Kimmelman v. Morrison, 477 U.S. 365,380 (1986) (noting that " $[\mathrm{t}]$ he constitutional rights of criminal defendants are granted to the innocent and the guilty alike"). 
to allow for investigation is clearly not a panacea, ${ }^{27}$ it is a low-cost and simple solution to one large obstacle to the effective assistance of counsel. Given Williams and Wiggins, and lessons about the need for adequate investigation to protect against wrongful conviction, it is important to consider how restrictive discovery can violate the right to the effective assistance of counsel. Courts-and legislatures-should build on the momentum of Wiggins to recognize that investigation is one of the core functions of defense counsel. It is a defining feature that gives meaning to the effective assistance of counsel. It is time to take the next logical step toward understanding how defense counsel's investigative ability is inextricably intertwined with the constraints that the discovery process places on defense counsel's access to information.

In Part I, this article explores defense counsel's duty to investigate in the context of the Sixth Amendment and considers the cases defining the duty. It focuses on Wiggins to demonstrate how the Supreme Court has recently given new force to the duty to investigate. Part II links the duty to the discovery process and returns to the case of Jane Smith to understand how restrictive discovery statutes, such as those in New York, block the effective assistance of counsel. Part III summarizes the purpose of pretrial discovery in criminal cases and discusses why the three major contentions in support of restrictive discovery-likely perjury by the defendant, lack of reciprocity in the discovery process, and potential witness intimidation-lack validity. This article concludes by suggesting that the prophylactic rule of open file discovery is an appropriate remedy for the constitutional conflict between the duty to investigate and state barriers to the information necessary to carry out that duty.

\section{The Evolution of Defense Counsel's Sixth Amendment Duty to Investigate}

A criminal defendant's Sixth Amendment right "to have the Assistance of Counsel for his defence" 28 is the right to effective assistance of counsel. ${ }^{29}$ The underlying purpose of this right is to allow "the accused to require the prosecution's case to survive the cruci-

27. A meaningful duty to investigate, and the discovery necessary to give it real teeth, would be only a starting point. As acknowledged infra note 111 and accompanying text, there are a number of systemic obstacles, such as insufficient investigatory resources, that could also obstruct the duty to investigate.

28. U.S. Const, amend. VI.

29. McMann v. Richardson, 397 U.S. 759, 771 n.14 (1970). 
ble of meaningful adversarial testing." 30 In other words, the right to effective assistance advances the same goal as that of the criminal justice system more generally: fairness within the adversary process, with the ultimate objective that the guilty are convicted and the innocent are acquitted. ${ }^{31}$

\section{A. The Central Role Investigation Plays in Providing Effective Assistance of Counsel}

The Supreme Court has emphasized the importance of fact development in criminal cases, noting that:

The need to develop all relevant facts in the adversary system is both fundamental and comprehensive. The ends of criminal justice would be defeated if judgments were to be founded on a partial or speculative presentation of the facts. The very integrity of the judicial system and public confidence in the system depend on full disclosure of all the facts, within the framework of the rules of evidence. ${ }^{32}$

Such fact development cannot take place without investigation. In turn, adversarial balance cannot take place without investigation by both the prosecution and the defense. Thus, defense counsel's duty to investigate rests on the recognition of pretrial investigation as "perhaps, the most critical stage of a lawyer's preparation." 33

30. United States v. Cronic, 466 U.S. 648, 656 (1984); see also Strickland v. Washington, 466 U.S. 668, 685 (1984) ("The right to counsel plays a crucial role in the adversarial system embodied in the Sixth Amendment, since access to counsel's skill and knowledge is necessary to accord defendants the 'ample opportunity to meet the case of the prosecution' to which they are entitled" (quoting Adams v. United States ex rel. McCann, 317 U.S. 269, 275-76 (1942))).

31. See Cronic, 466 U.S. at 655-56; see also Strickland, 466 U.S. at 686 ("The benchmark for judging any claim of ineffectiveness must be whether counsel's conduct so undermined the proper functioning of the adversarial process that the trial cannot be relied on as having produced a just result"); Herring v. New York, 422 U.S. 853,862 (1975) (remarking that "[t]he very premise of our adversary system of criminal justice is that partisan advocacy on both sides of a case will best promote the ultimate objective that the guilty be convicted and the innocent go free").

32. United States v. Nixon, 418 U.S. 683, 709 (1974); see also Taylor v. Illinois, 484 U.S. 400, 408-09 (1988).

33. House v. Balkcom, 725 F.2d 608, 618 (11th Cir. 1984) (internal quotations omitted); see also Moore v. United States, 432 F.2d 730, 735 (3rd Cir. 1970) which noted that:

Adequate preparation for trial often may be a more important element in the effective assistance of counsel to which a defendant is entitled than the forensic skill exhibited in the courtroom. The careful investigation of a case and the thoughtful analysis of the information it yields may disclose evidence of which even the defendant is unaware and may suggest issues and tactics at trial which would otherwise not emerge. 
As early as 1932, in its first decision explaining the right to counsel, the Supreme Court linked the right to the investigative function of defense counsel. In Powell v. Alabama, ${ }^{34}$ the Court stressed the particular need for counsel in the period between the defendant's arraignment and the beginning of trial "when consultation, thorough-going investigation and preparation were vitally important."35 Adversarial testing requires thorough exploration of defenses as to both guilt and potential penalties and also investigation into the prosecution's case. ${ }^{36}$ In short, to provide effective assistance of counsel consistent with the Sixth Amendment, defense counsel has an independent duty to investigate the case. ${ }^{37}$

In 1984, the Supreme Court examined David Leroy Washington's claim that his attorney's failure to investigate and present mitigating evidence at his capital sentencing hearing constituted ineffective assistance of counsel. ${ }^{38}$ In its seminal decision in Strickland $v$. Washington, the Supreme Court explained for the first time the test for ineffective assistance claims where defense counsel "simply ... fail[ed] to render 'adequate legal assistance." "39 The

34. 287 U.S. 45 (1932).

35. Id. at 57 (reversing the convictions of the defendants due to a violation of their right to counsel as a matter of due process). In Powell, the Supreme Court found a constitutional right to appointed counsel, for the first time, under the due process clause of the Fourteenth Amendment. Id. at 73. Eight years later, in Johnson v. Zerbst, the Court ground the right to appointed counsel in the Sixth Amendment. 304 U.S. 458, 462-63 (1938). It was not until 1963, with its decision in Gideon v. Wainwright, that the Court made this Sixth Amendment right applicable to the states. 372 U.S. 335, 339 (1963). A defendant's Sixth Amendment right to counsel attaches at all critical stages of a criminal case. United States v. Wade, 388 U.S. 218, 224 (1967).

36. See Kimmelman v. Morrison, 477 U.S. 365, 384 (1986) (stating that the adversarial "testing process generally will not function properly unless defense counsel has done some investigation into the prosecution's case and into various defense strategies"); see also Coles v. Peyton, 389 F.2d 224, 226 (4th Cir. 1968) ("Counsel must conduct appropriate investigations, both factual and legal, to determine if matters of defense can be developed, and to allow himself enough time for reflection and preparation for trial").

37. Balkcom, 725 F.2d at 618. One judge, discussing defense counsel's duty to investigate, emphasized that "[p]reparation is the sine qua non of effective assistance." Langone v. Smith, 682 F.2d 287, 289 (2d Cir. 1982) (Oakes, C.J., dissenting from denial of rehearing en banc).

38. Strickland v. Washington, 466 U.S. 668, 671 (1984).

39. Id. at 686 (quoting Cuyler v. Sullivan, 446 U.S. 335, 344 (1980)). There are, in Sixth Amendment jurisprudence, two different types of ineffective assistance of counsel: system ineffectiveness and attorney ineffectiveness. "In the former, the trial is unfair because of systemic conditions operating apart from either the performance of individual counsel or the facts of particular cases. . . In the latter ... unfairness is a product of attorney incompetence." Joe Margulies, Criminal Law: Resource Deprivation \& the Right to Counsel, 80 J. CRIM. L. \& CRIminology 673, 676 (1989-90). The difference is significant because in claiming systemic ineffectiveness, the defendant 
Strickland Court established a two-prong test for actual ineffectiveness under which a defendant must show that counsel's representation was deficient and that the deficiency prejudiced the defendant's case. ${ }^{40}$ To prove deficiency, a defendant must show that the attorney's "representation fell below an objective standard of reasonableness" as measured by "prevailing professional norms." 41 To prove prejudice, a defendant must show "that the decision reached would reasonably likely have been different absent the errors." 42 In other words, the requirement is that, without counsel's deficient performance, there is a reasonable probability that the factfinder would have reached a different result such as acquittal, conviction on a lower charge, or imposition of a different sentence. ${ }^{43}$

The claimed deficiency in Strickland was a failure to investigate. ${ }^{44}$ The Court described the Sixth Amendment duty to investigate as "a duty to make reasonable investigations or to make a reasonable decision that makes particular investigations unnecessary." 45 The key is strategic decision-making: an attorney can either make a strategic choice after thorough investigation, or can make a strategic choice that limited investigation is reasonable, given the facts and circumstances of the particular case. ${ }^{46}$

need not show that he was prejudiced by the ineffectiveness; in addition, the relief for systemic claims is prophylactic. The inability to investigate due to restrictive discovery rules is systemic ineffectiveness. This article's suggestion of prophylactic relief in the form of open file discovery is explored briefly in the Conclusion.

40. Strickland, 466 U.S. at 687; see also Yarborough v. Gentry, 124 S. Ct. 1, 4 (2003) (noting that a defendant's Sixth Amendment right to effective assistance of counsel is denied when an attorney's performance falls below an objective standard of reasonableness and thereby prejudices the defendant).

41. Strickland, 466 U.S. at 688.

42. Id. at 696.; see also Scarpa v. DuBois, 38 F.3d 1, 8 (1st Cir. 1994) (acknowledging that "in itself, dreary lawyering does not offend the Constitution").

43. Strickland, 466 U.S. at 695 . The Strickland Court found that a defendant's burden is not so high as to show that the errors "more likely than not altered the outcome in the case." Id at 693. Rather, the Court relied on the "reasonable probability" language as more appropriate because finality concerns are somewhat weaker when the claim is that the proceeding itself was unreliable. Id. at 694 . If the case ended in a guilty plea, a defendant claiming ineffective assistance must show that trial counsel probably would have advised against the guilty plea absent the deficiency, and that this probably would have led to acquittal at trial. See Hill v. Lockart, 474 U.S. 52, 57 (1985) (adopting two-part Strickland test for ineffective assistance of counsel claims in guilty plea context).

44. Strickland, 466 U.S. at 675.

45. Id. at 691 .

46. Id. at 690-91. The Strickland Court noted that in undertaking an ineffective assistance of counsel claim based on all the facts and circumstances of the case, a court "should keep in mind that counsel's function, as elaborated in prevailing profes- 
Under Strickland, it is not failure to introduce certain mitigating evidence that has constitutional significance; indeed, earlier Supreme Court cases found no Sixth Amendment violation where counsel did not introduce any mitigating evidence at all. ${ }^{47}$ Rather, it is counsel's failure to investigate enough to make an informed decision about whether or not to introduce particular evidence that violates the right to effective assistance of counsel: "Ultimately, the courts are concerned that counsels' decisions reflect 'informed, professional deliberation' rather than 'inexcusable ignorance or senseless disregard of their clients' rights.' "48

Despite such clear recognition throughout the cases of the critical role that defense counsel's investigation plays in ensuring fairness in the criminal justice system, and the square placement of pretrial investigation among a defendant's Sixth Amendment rights, courts analyzing failure-to-investigate claims have not always treated them reverently. This treatment may stem from some of the same concerns that led the Strickland Court to apply a presumption of strategic decision-making when analyzing post-conviction claims of ineffective assistance-most notably the specter of a proliferation of mini-trials on the issue of attorney performance. ${ }^{49}$ Defendants claiming ineffective assistance must overcome "a strong presumption" that counsel's conduct was "sound trial strategy." 50 Under this standard, courts have often excused basic failures to investigate as reasonable, strategic decisions on the part of defense counsel. ${ }^{51}$ Strickland itself is an example: it was a capital case in which defense counsel's entire mitigation investigation for

sional norms, is to make the adversarial testing process work in the particular case." Id. at 690 .

47. See Burger v. Kemp, 483 U.S. 776, 788-96 (1987) (characterizing defense counsel's failure to put on any mitigating evidence at all in capital sentencing hearing as strategic because counsel did some investigation into such potential evidence and concluded that it would do more harm than good at the hearing); see also Darden v. Wainwright, 477 U.S. 168, 184-87 (1986) (same).

48. Washington v. Strickland, 693 F.2d 1243, 1251 (5th Cir. 1982), rev'd 466 U.S. 668 (1984) (quoting United States v. Bosch, 584 F.2d 1113, 1122 (1st Cir. 1978)).

49. Strickland, 466 U.S. at 689.

50. Id. at 698 (internal quotation omitted).

51. See, e.g., Knighton v. Maggio, 740 F.2d 1344, 1350 (5th Cir. 1984) (characterizing trial attorney's decision to do little investigation and offer no evidence at capital sentencing phase as strategic); see also Lindstadt v. Keane, 239 F.3d 191, 199 (2d Cir. 2001) ("The Strickland standard is rigorous, and the great majority of habeas petitions that allege constitutionally ineffective counsel founder on that standard"); Martin C. Calhoun, Note \& Comment, How to Thread the Needle: Toward a Checklist-Based Standard for Evaluating Ineffective Assistance of Counsel Claims, 77 GEo. L.J. 413, 414 \& n.11 (1988) (noting that the Supreme Court has rejected all four ineffectiveness claims it decided in the four years after Strickland and that circuit courts have only 
the sentencing hearing - a hearing at which counsel presented no evidence at all-consisted of conversations with his client and phone contact with his client's wife and mother. ${ }^{52}$ The Court categorized this failure to investigate as "strategic" in denying the defendant's Sixth Amendment claim; counsel's strategy was to focus on defendant's remorse and acceptance of responsibility in a plea for mercy to the exclusion of mitigation evidence at the sentencing hearing. ${ }^{53}$

A number of courts have undertaken a more forceful analysis of failure-to-investigate claims. For example, the Eight Circuit found ineffective assistance when counsel investigated and presented an alibi defense (albeit a weak one) at trial but failed to investigate the possibility that someone else actually committed the crime. ${ }^{54}$ The court gave the duty to investigate real meaning: "Reasonable performance of counsel includes an adequate investigation of the facts of the case, consideration of viable theories, and development of evidence to support those theories. Counsel has 'a duty . . . to investigate all witnesses who allegedly possessed knowledge con-

granted $4.3 \%$ of the 702 ineffectiveness claims they addressed in that same time period).

52. Strickland, 466 U.S. at 673.

53. $I d$. at 718. One standard does seem clear: the total failure to investigate would violate the Sixth Amendment. United States v. Gray, 878 F.2d 702, 711 (3d Cir. 1989) (noting that "the courts of appeals are in agreement that failure to conduct any pretrial investigation generally constitutes a clear instance of ineffectiveness"); see also Knighton, 740 F.2d at 1351 (stating that, if defendant's claim of total failure to investigate "were supported by the record, the sixth amendment standard would not have been met"). The unfortunate reality is that many case are not investigated at all, due to a number of factors which include plea bargaining that takes place very early in the case, perhaps as early as the initial appearance (which may also be the first time the defendant meets his lawyer) and inadequate investigatory resources that lead to triage-like decisions about which cases to investigate. See John Mitchell, Redefining the Sixth Amendment, 67 S. CAL. L. REv. 1215, 1274-80 (1994) (analogizing allocation decisions that defenders in the lower criminal courts must make to medical triage decisions). See generally Michael McConville \& Chester L. Mirsky, Criminal Defense of the Poor in New York City, 15 N.Y.U. Rev. L. \& Soc. Change 581 (1987) (relaying results of study finding poor quality of indigent defense in New York City). Broad discovery, early in the process, can only alleviate such problems, either by easing strained investigatory resources with investigatory leads that would otherwise need to be tracked down, or by providing defense counsel with some information about the case so there is less of an informational imbalance in the plea bargain process. See, e.g., N.J. Cr. R. 3:13-3(a) (2003) (allowing pre-indictment discovery when prosecutor makes a pre-indictment plea offer).

54. Hendersen v. Sargent, 926 F.2d 706, 711-12 (8th Cir. 1991) (reversing conviction where counsel failed to investigate evidence that victim's husband, or possibly another man with ties to the victim, had killed her because "[ $t]$ he decision to interview a potential witness is not a decision related to trial strategy. Rather, it is a decision related to adequate preparation for trial" (internal quotations omitted)). 
cerning [the defendant's] guilt or innocence." W5 While this rather ambitious statement differs from the Supreme Court's articulation of the duty to investigate, ${ }^{56}$ it does evidence great concern about sanctioning attorney behavior that results in the termination, or weakening, of viable defenses. It also mirrors the American Bar Association ("ABA") and other professional standards for defense counsel governing investigation. ${ }^{57}$

Most significantly, the Supreme Court's treatment of failure-toinvestigate claims has become substantially more exacting since Strickland. In 2000, the Supreme Court reversed Terry Williams's death sentence based on his attorney's failure to investigate mitigating evidence for his sentencing hearing. ${ }^{58}$ Williams $v$. Taylor was the first Supreme Court decision to find ineffective assistance of counsel under the two-prong Strickland standard, and it did so based on a failure to undertake reasonable investigation. The Court decided Williams during the 1999-2000 term, when "[a]lmost one quarter of its cases involved either claims of ineffective assistance or failures on the part of defense counsel that worked to the detriment of their client's right."59 A summary of the Court's term noted that "[o]ne trend emerging from this term's decisions is seen in the Court's concern with ineffective assistance of counsel."60 This trend, together with the decision in Williams, "seemed to send

55. Id. at 711 (quoting Lawrence v. Armontrout, 900 F.2d 127, 130 (8th Cir. 1990)); Wade v. Armontrout, 798 F.2d 304, 307 (8th Cir. 1986) (finding that defense counsel's "failure to investigate was not the result of strategy or a reasonable decision not to investigate, but rather [stemmed] from a lack of preparation").

56. See Strickland, 466 U.S. at 691 (describing duty to investigate as duty to "make reasonable investigations or to make a reasonable decision that makes particular investigations unnecessary").

57. See Compendium of Standards for Indigent Defense Systems (Neal Miller \& Peter Ohlhausen eds., 2000) (listing national, state, and local standards relating to five functions of indigent defense, including "Investigation and Preparation," in a document prepared by the Institute for Law and Justice and supported by a contract with the Department of Justice), available at http://www.ojp.usdoj.gov/indigentdefense/compendi um/pdf.htm (last visited May 10, 2004). The American Bar Association Standards for Criminal Justice state that "[d]efense counsel should conduct a prompt investigation of the circumstances of the case and explore all avenues leading to facts relevant to the merits of the case and the penalty in the event of conviction." Id. (emphasis added).

58. Williams v. Taylor, 529 U.S. 362, 396 (2000) (evidentiary omissions at trial "clearly demonstrate that trial counsel did not fulfill their obligation to conduct a thorough investigation of the defendant's background" (citing 1 AM. BAR Ass'N, ABA Standards for Criminal Justice 4-4.1, commeritary, 4-55 (2d ed. 1980))).

59. Laurence Benner et al., Criminal Justice in the Supreme Court: A Review of United States Supreme Court Criminal and Habeas Corpus Decisions (Oct. 4, 1999Oct. 1, 2000), 37 Cal. W. L. Rev. 239, 318 (2001).

60. Id. 
a clear signal that the Strickland standard can no longer be used to whitewash such failures." 61 Then, only three years later, in Wiggins $v$. Smith, the Court reversed a death sentence for ineffective assistance of counsel-once again based on a failure to investigate. ${ }^{62}$

The facts of Wiggins are very similar to those in Strickland, decided nineteen years earlier. To better understand what lies beneath the Court's renewed vigor in analyzing investigatory failures, it is worth taking a closer, comparative look at the Wiggins and Strickland cases before exploring the connection between investigation and pretrial discovery.

\section{B. From Strickland to Wiggins: Giving Meaning to the Duty to Investigate}

Both Wiggins and Strickland were capital cases involving Sixth Amendment claims of ineffective assistance of counsel due to defense counsel's failure to investigate. Both failures related to the lack of mitigation evidence at the sentencing hearing. Both decisions were authored by Justice O'Connor and were decided 7-2. The results, however, were strikingly dissimilar: Kevin Wiggins awaits a new sentencing hearing ${ }^{63}$ while the State of Florida electrocuted David Leroy Washington on July 13, $1984 .{ }^{64}$

\section{Investigation and Mitigation Evidence in Strickland and Wiggins}

In Strickland, defense counsel conducted no investigation into potential character witnesses for Washington and made no request for a psychiatric exam, "since his conversations with his client gave no indication that [his client] had psychological problems." 65 This was despite the fact that Washington told the trial judge that at the time of the crimes "he was under extreme stress caused by his inability to support his family," and he had also described to the

61. Id. As one defense attorney noted, "[w]hat is remarkable about Williams and Wiggins is that neither of those cases are remarkable. . [N]either Williams nor Wiggins involved a change in the standard governing [ineffective assistance] claims. Instead, it was the Supreme Court merely modeling the claims and the approach." John Council, Litigate or Mitigate?: Supreme Court Opinion Puts a Wrinkle in Death-Penalty Appeals, TEx. LAw., Jan. 26 2004, at 1 (quoting Jim Marcus, executive director of the Texas Defender Service in Houston).

62. Wiggins v. Smith, 123 S. Ct. 2527, 2544 (2003).

63. Id. at 2544.

64. See Death Penalty Information Center (2004), at http://www.deathpenalty info.org (last visited May 18, 2004); see also Strickland v. Washington, 467 U.S. 1267 (1984) (denying petition for rehearing).

65. Strickland v. Washington, 466 U.S. 668, 673 (1984). 
judge his planning for, and participation in, "three groups of crimes, which included three brutal stabbing murders, torture, kidnaping, severe assaults, attempted murders, attempted extortion, and theft."66 Defense counsel's entire investigation consisted of speaking with his client, and speaking by phone with Washington's wife and mother; he made one unsuccessful attempt to meet these two family members in person.

In Wiggins, the attorneys investigated three source of potential mitigation evidence: 1) they had a psychologist conduct IQ and psychological tests on Wiggins; 2) they had access to a Probation and Parole Department pre-sentence report which included a onepage, self-reported description of Wiggins's "misery as a youth" and "disgusting" background; and 3) they "[t]racked down" Social Services records documenting Wiggins's various foster care placements. ${ }^{67}$ Although the Court did not mention it, Wiggins's attorneys presumably spoke with their client, just as defense counsel in Strickland spoke with his-a consultation that the Strickland Court noted as part of the "investigation" and which, indeed, constituted most of the investigation. ${ }^{68}$ Wiggins's attorneys did not uncover much of what the Supreme Court called a "bleak life history," one that included reports of eating paint chips and garbage, being hospitalized after his alcoholic mother held his hand on a stove burner, being physically abused and raped in two foster homes, and living intermittently on the streets from age sixteen. ${ }^{69}$ This history was fully explored only after the trial in post-conviction proceedings. ${ }^{70}$

Not surprisingly, after so little investigation, neither defense counsel put on much-if any-of a mitigation case. At Washington's sentencing hearing, defense counsel focused on arguing to the judge that his client's "remorse and acceptance of responsibility justified sparing him from the death penalty." 71 He also pointed out his client's lack of criminal history and extreme mental disturbance at the time of the crimes but based both arguments only on Washington's own testimony from the plea colloquy that took place in front of the same judge. ${ }^{72}$ The Strickland Court noted two reasons for counsel's decision "not to present and hence not to look further for evidence concerning respondent's character and

66. Id at 671-72.

67. Wiggins, $123 \mathrm{~S}$. Ct. at 2536.

68. Strickland, 466 U.S. at 673.

69. Wiggins, $123 \mathrm{~S}$. Ct. at 2533.

70. Id. at 2532-33.

71. Strickland, 466 U.S. at 673.

72. Id. at 672-74. 
emotional state."73 First, counsel felt a "sense of hopelessness" after his client pled guilty and confessed, against his advice, to such gruesome crimes. ${ }^{74}$ Second, he wanted to stick to the plea colloquy so that the prosecution could not cross-examine Washington or put on psychiatric evidence of its own. ${ }^{75}$ The Court found that counsel's decision to focus on acceptance of responsibility was driven by his knowledge of the judge's reputation for placing value on remorse and such acceptance. Indeed, the trial judge told Washington that he had "a great deal of respect for people who are willing to step forward and admit their responsibility."76 He then sentenced him to death. ${ }^{77}$

A similar scenario unfolded for Kevin Wiggins with respect to mitigation evidence. Wiggins was found guilty in a bench trial but had a jury for the sentencing phase of his capital murder trial. ${ }^{78}$ At the sentencing hearing, Wiggins's two attorneys basically retried the issue of guilt, offering evidence that Wiggins did not kill the victim by his own hand and thus was not eligible for the death penalty. They offered no evidence of Wiggins's life history despite promising the jury that they would do so. ${ }^{79}$ They did make a proffer to the court about the mitigation case they would have put on had the court granted their motion to bifurcate the sentencing hearing into two phases, one to address death penalty eligibility and the other to address mitigation. This would have included expert psychological testimony but not life history or family background. ${ }^{80}$ The jurors came back with a death sentence the same day they were charged. ${ }^{81}$

Despite these strong parallels, the two cases are dissimilar in their outcomes in the Supreme Court. In Strickland, the Court found that counsel's decision "not to seek more character or psychological evidence than was already in hand" was a reasonable strategy that was "well within the range of professionally reasonable judgment[]." 82 As for prejudice, the Court rejected it outright.

73. Id. at 673 .

74. Id. at 672 .

75. Id. at 673 .

76. Id.

77. Id. at 675 .

78. Wiggins v. Smith, 123 S. Ct. 2527, 2532 (2003).

79. Id.

80. Id.

81. Id.

82. Strickland, 466 U.S. at 699 . Although ultimately discounting the effect of counsel's state of mind, the majority mentioned his "sense of hopelessness" or how he "felt hopeless" four times in the opinion. Id. at 672-73, 699. Justice Marshall, dissenting, 
It found that the evidence Washington claimed his attorney should have offered could not have outweighed the overwhelming aggravating factors supporting imposition of the death penalty. ${ }^{83}$ In contrast, Wiggins held that defense counsel had not investigated potential mitigation evidence sufficiently to make a reasoned, strategic decision that they would not introduce such evidence at the hearing. ${ }^{84}$ With respect to the prejudice prong, since the mitigation evidence presented during the post-conviction phase of the case was "powerful," 85 the Court found that there was a reasonable probability that the jury would have returned a non-death sentence had they heard it. ${ }^{86}$

While counsel in both cases presented little-to-no mitigation evidence, the Wiggins Court made clear that the issue was "not whether counsel should have presented a mitigation case" but rather "whether the investigation supporting counsel's decision not to introduce mitigating evidence of Wiggins's background was itself reasonable." 87 The Court measured reasonableness against "prevailing professional standards," and found that counsel's investigation fell short. ${ }^{88}$

\section{Changes in Prevailing Professional Norms Explain Differing Outcomes in Strickland and Wiggins}

It is this reliance on prevailing professional norms that explains the difference between two such factually close cases. ${ }^{89}$ Norms

noted this "hopelessness" in deeming "[c]ounsel's failure to investigate . . particularly suspicious." Id. at 718. In fact, the majority implicitly conceded that defense counsel's decision that he would not present-and thus did not need to look forevidence relating to Washington's character and emotional state was not entirely strategic by noting two reasons for defense counsel's decision: "trial counsel's sense of hopelessness about overcoming the evidentiary effect of respondent's confessions to the gruesome crimes[, and] . . the judgment that it was advisable to rely on the plea colloquy for evidence about respondent's background and about his claim of emotional stress." Id. at 673. Clearly, hopelessness about the case is not a strategic reason for failing to investigate.

83. Id. at 699-700.

84. See Wiggins, $123 \mathrm{~S}$. Ct. at 2536.

85. Id. at 2542 .

86. Id. at 2543 .

87. Id. at 2536 (emphasis added).

88. Id. at 2537 (distinguishing Strickland as a "precedent [] in which [the Court] found limited investigations into mitigating evidence to be reasonable").

89. There are, certainly, some factual differences between the Strickland and Wiggins cases beyond the actual results. The Strickland sentencing hearing took place in front of a judge, who defense counsel knew from practice to care deeply about acceptance of responsibility. This allowed the Court to put aside the attorney's hopelessness and deem his meager investigation "strategic," since further investigation would have 
governing defense counsel investigation have evolved in the years between the two decisions. These norms, in turn, are driven by the ongoing debate over the death penalty which focuses on wrongful convictions and their causes.

In Wiggins, Justice O'Connor repeated the Court's holding from three years earlier in Williams $v$. Taylor, referencing professional norms: failure to present mitigation evidence could not be strategic where "counsel had not 'fulfill[ed] their obligation to conduct a thorough investigation of the defendant's background" " before deciding how to proceed at the sentencing hearing. ${ }^{90}$ The Wiggins Court went on to find that Wiggins's attorneys' reliance on the short pre-sentence investigation report and their client's Department of Social Service records "fell short of the professional standards that prevailed in Maryland in 1989" requiring "preparation of a social history report." 91 Counsel also fell short of the ABA's "well-defined norms," which call for investigation into "all reasonably available mitigating evidence and evidence to rebut any aggravating evidence that may be introduced by the prosecutor." 92 Characterizing counsel's failure to follow these norms as an "aban-

been-in his and the Court's view-pointless given the circumstances. Strickland v. Washington, 466 U.S. 668, 699 (1984).

In contrast, Wiggins's attorneys' addressed to a jury which, as a group of strangers, has no record of a collective, general predisposition toward favoring the defendant accepting responsibility for his actions. One could certainly characterize counsel's decision to argue lack of guilt on the capital charge-to the exclusion of mitigation-as a strategic choice driven by the concern that mitigation would appear to the jury to be an argument in the alternative that would weaken the primary argument. In Wiggins, this would not be as strong a concern as in a case where counsel re-argues total lack of guilt to the jury; this is because Wiggins's lawyers were conceding that he played some role in the murder but that he was not directly responsible. See Wiggins, $123 \mathrm{~S}$. Ct. at 2532. Still, whether or not to argue in the alternative-or to argue something that a jury might construe as alternative-is a strategic decision that defense counsel must make in many cases. In fact, Wiggins's attorneys argued to the trial judge that failure to bifurcate the sentencing hearing would result in dilution of their presentation about Wiggins's lack of direct responsibility. Id.

In short, these differences are not so great as to explain the different outcomes; rather, the evolution of professional norms and the backdrop of the death penalty debate are critical to understanding the Court's much more exacting analysis of the duty to investigate in Wiggins.

90. Wiggins, 123 S. Ct. at 2532 (quoting Williams v. Taylor, 529 U.S. 362, 396 (2000)); see also supra notes 58-61 and accompanying text (discussing Williams). This standard of thorough background investigation is drawn from the American Bar Association's STANDARDS FOR CRIMINAl. JuSTICE. See Williams, 529 U.S. at 396 (referencing 1 ABA Standards For CRiminal Justice 4-4.1, commentary p. 4-55 (2d ed. 1980)).

91. Wiggins, $123 \mathrm{~S}$. Ct. at 2536.

92. $\mathrm{Id}$. at 2537 (quoting ABA Guidelines for the Appointment ANd Performance of Counsel in Death Penalty Cases $\$ 11.4 .1$ (1989)). 
don[ment of] their investigation ... after having acquired only rudimentary knowledge of [Wiggins'] history from a narrow set of sources," the Court found that the failure to investigate stemmed from "inattention, not reasoned strategic judgment."93 Professional standards are integral to the Sixth Amendment analysis in Wiggins; the constitutional right is explicitly attached to, and depends upon, the current state of the professional norm. ${ }^{94}$

In contrast to Wiggins, the Strickland decision never specified any of the prevailing norms governing investigation generally or investigation into mitigation at a capital sentencing hearing; it merely cited, almost in passing, the entire portion of the ABA's Standards for Criminal Justice on "The Defense Function." 95 Indeed, the Court noted that the definition of the duty to investigate requires "no special amplification" beyond an assessment of "reasonableness in all the circumstances, applying a heavy measure of deference to counsel's judgments." 96 The level of specificity of, and reliance upon, the professional standards gives Wiggins much more force than Strickland with respect to the constitutional duty to investigate. ${ }^{97}$

93. Id.

94. This reliance on prevailing norms to set the constitutional floor is not unique to Sixth Amendment jurisprudence. See Trop v. Dulles, 356 U.S. 86, 101 (1958) (noting that the Eighth Amendment "must draw its meaning from the evolving standards of decency that mark the progress of a maturing society"); see also Lawrence v. Texas, 123 S. Ct. 2472, 2480 (2003) (noting, in overruling its earlier decision in Bowers, that "our laws and traditions in the past half century are of most relevance here. These references show an emerging awareness that liberty gives substantial protection to adult persons in deciding how to conduct their private lives in matters pertaining to sex"); Atkins v. Virginia, 536 U.S. 304, 311 (2002) ("A claim that punishment is excessive is judged not by the standards that prevailed in 1685 when Lord Jeffreys presided over the "Bloody Assizes" or when the Bill of Rights was adopted, but rather by those that currently prevail").

95. Strickland v. Washington, 466 U.S. 668, 688 (1984) ("Prevailing norms of practice as reflected in American Bar Association standards and the like, e.g., ABA STANDARDS FOR CRiminal Justice 4-1.1 to 4-8.6 (2d ed. 1980) ("The Defense Function"), are guides to determining what is reasonable, but they are only guides").

96. Id. at $690-91$.

97. See, e.g., Leading Cases, supra note 19, $278-79$ (2003) ("In Wiggins, the Court promoted a longstanding guideline of the ABA - that capital counsel thoroughly explore the social background of the defendant-to the level of constitutional mandate"). Id. at 282. The capital defense bar's reaction to Wiggins has been swift. In April, 2004, the Habeas Assistance \& Training Counsel and Federal Death Penalty Resource Counsel Projects sponsored "Wiggins Mitigation Training" to focus on the implications of the decision. See Death Penalty and Capital Habeas Corpus 2004 Training for Defense Counsel and Mitigation Specialists, at http://www.capdefnet.org/ fd prc/contents/shared_files/upcom ing_seminars/upcoming.htm (last visited May 12, 2004) (announcing training and noting that "the [Wiggins] court found that the failure to seek the services of a mitigation specialist or social history investigator to conduct a 


\section{Recent Death Penalty Debates and the Evolution of Investigation Standards}

Recent debates over fairness in the death penalty, and in particular the current dialogue about wrongful conviction and its causes, drive the evolution of norms surrounding the duty to investigate. These debates lie just beneath the surface of the Court's greater scrutiny of the failure to investigate in Williams and Wiggins. A significant number of highly-publicized cases of wrongful conviction of innocent men and women-some of whom came close to execution only to be exonerated by DNA or other evidence-has led to continued inquiry into ways to protect against wrongful conviction. Full investigation of the case in which the trial lawyer's original investigation was inadequate is one way to exonerate innocent defendants. ${ }^{98}$ The commentary accompanying the recentlypublished Revised ABA Guidelines for the Appointment and Performance of Defense Counsel in Death Penalty Cases lists "inadequate investigation by defense attorneys," along with such things as "faulty eyewitness identification, coerced confessions, prosecu-

comprehensive investigation into the entire life of the client fell below existing professional norms, constituted an unreasonable, incomplete investigation").

98. See, e.g., Dan Malone, When the System Fails; Cuban Immigrant Freed 14 Years After Death Sentence, Dallas Morning News, Apr. 23, 1997 at 1A (describing the case of Roberto Miranda who was freed from prison only after an appellate attorney investigated the case and located evidence that led the prosecutor to dismiss the charges); see also Innocence Project, Poor Defense Lawyering, at http:// www.innocenceproject.org/c auses/badlawyering.php (2001) (noting that "[f]ailure to investigate, failure to call witnesses, inability to prepare for trial (due to caseload or incompetence), are a few examples of poor lawyering").

There have been calls for a number of other major systemic reforms including:

1) More reliable identification procedures, see NAT'L INST. OF JUSTICE, U.S. Dep't of Justice, Eyewitness Evidence: A Trainer's Manual For LAW ENFORCEMENT v (2003), available at http://nij.ncjrs.org/publications/ pubs_db.asp; see also OfFice of the AtTorney Gen., N.J. DeP'T of Law \& Pub. Safety, Attorney General Guidelines for Preparing and Conducting Photo and Live Lineup Identification Procedures (2001), available at http:/www.state.nj.us/lps/dcj/agguide/photoid.pdf;

2) Videotaping of suspects' statements, see Steve Mills \& Michael Higgins, Cops Urged To Tape Their Interrogations; City Videotapes Only Confessions, ChI. Trib., Jan. 6, 2002, at 1; see also Steven A. Drizin \& Richard A. Leo, Problem of False Confessions in the Post-DNA World, 82 N.C. L. REv. 891, 997 (2004) (noting that a "videotape will capture any police abuses and/or improprieties as well as protect detectives from false accusations");

3) Better funding for counsel in capital cases, see Bruce Moyer, DNA Legislation Scores Wide Support, FED. LAw., Nov.-Dec. 2003, at 10 (discussing the Advancing Justice Through DNA Technology Act of 2003 (H.R. 3214), approved by the House Judiciary Committee in October 2003, which includes a provision for increased funding for counsel in capital cases). 
torial misconduct, and false jailhouse informant testimony" as contributing factors to wrongful convictions in capital and non-capital cases. ${ }^{99}$ These factors are not unrelated; thorough investigation into the prosecution's case, for example, can expose weaknesses in an eyewitness' identification, the factor often noted as the primary cause of wrongful convictions. ${ }^{100}$

Wrongful conviction cases have contributed greatly to the sea changes in public and professional opinion about administration of the death penalty in the nineteen-year interim since Strickland. ${ }^{101}$

99. Am. Bar Ass'n, ABA Guidelines for the Appointment and Performance of Counsel in Death Penalty Cases Guideline 10.7 commentary (2003) [hereinafter 2003 ABA GuIDELINES FOR COUNSEL] (providing commentary accompanying guideline on investigation) (emphasis added); see also Gary Goodpaster, $A d$ versary System, Advocacy, and Effective Assistance of Counsel in Criminal Cases, 14 N.Y.U. Rev. L. \& Soc. Change 59, 90-91 (1986) (listing "Failure to conduct an adequate pretrial investigation" as one of the "major generic deficiencies of criminal defense attorneys," based on review of ineffective assistance cases); Barbara R. Levine, Preventing Defense Counsel Error-An Analysis of Some Ineffective Assistance of Counsel Claims and Their Implications for Professional Regulation, 15 U. TOL. L. REv. 1275, 1371 (1984) (finding, in a statistical analysis of a sample of ineffective assistance of counsel claims in Michigan, that the most frequent ineffective assistance claim is the failure to investigate or introduce defense evidence). A new subsection to the ABA's death penalty investigation guideline, added in the 2003 update, states that "[c]ounsel at every stage have an obligation to conduct a full examination of the defense provided to the client at all prior phases of the case." 2003 ABA Guidelines FOR Counsel Guideline 10.7.B.1. This seems designed to emphasize the need to remedy inadequate investigation at the trial level; see also AM. Civil Liberties Union, 101 Almost Dead Men Walk (listing ineffective assistance as one of the systemic errors that sends innocent people to death row and noting that defense counsel may miss key pieces of potentially exonerating information due to failure to investigate), available at http://archive.aclu.org/features/Long MoratoriumFactSheet.pdf.

100. See, e.g., Robert D. McFadden, Official Says DNA \& Alibis Clear Suspect in Sex Attacks, N.Y. Times, Feb. 27, 2004, at B1 (quoting Peter Neufeld, co-founder of the Innocence Project, as stating that "[t]he single greatest cause of wrongful convictions is lineup misidentifications caused by unreliable police lineup procedures").

101. For example, on January 31, 2000, Illinois Governor George Ryan declared a moratorium on all executions, noting that in the period since 1977, Illinois had executed twelve inmates and released thirteen from death row. He then appointed a commission to study issues of fairness in administration of the death penalty, focusing on the causes of wrongful conviction. Timeline: Illinois Governor's Commission on Capital Punishment, at http://www.deathpenaltyinfo.org/timeline/pdf (last visited May 18, 2004). Peter Neufeld and Barry Scheck at the Innocence Project have done groundbreaking work in the area of wrongful conviction, see Innocence Project, at www.innocenceproject.org. (last visited May 18, 2004), as have Northwestern's Medill Journalism School Professor David Protess and his students, using "the techniques of investigative journalism, [to] expose[] tragic miscarriages of justice in a number of high-profile cases in Illinois." Bob Herbert, Returned to Life, N.Y. Times, Dec. 5, 2003, at A39 (describing the great impact that Professor Protess' and his students' work has had). 
At the time of Washington's trial in $1976,{ }^{102}$ the ABA did not have national guidelines with respect to capital case representation. ${ }^{103}$ The organization adopted guidelines in 1989 (the year the Wiggins case was tried) and called for "independent investigations relating to the guilt/innocence phase and to the penalty phase" that counsel must undertake "regardless of any admission or statement by the client concerning facts constituting guilt." 104 In 2003, the ABA replaced these guidelines with even more exacting ones that demand that "counsel at every stage have an obligation to conduct thorough and independent investigation."105 The ABA commentary to the guideline on investigation states explicitly that it is the developing understanding about the causes of wrongful convictions that has driven the evolving standards. Such concerns "underscore[] the importance of defense counsel's duty to take seriously the possibility of the client's innocence, to scrutinize carefully the quality of the state's case, and to investigate and re-investigate all possible defenses." 106

While the death penalty stands apart from all other penalties, ${ }^{107}$ the concerns that fuel the debate over fairness in the death penalty are certainly not limited to the capital context. The constitutional principles relating to the duty to investigate apply equally to the

102. See Washington v. Strickland, 673 F.2d 879, 883 (5th Cir. 1982), rev'd 466 U.S. 668 (1984).

103. See Am. Bar Ass'n, ABA Guidelines for the Appointment and Performance of Defense Counsel in Death Penalty Cases i (1989) ("While some local standards may exist for capital representation, national guidelines on the assignment and performance of counsel in capital cases did not exist prior to these Guidelines").

104. Id. at Guideline 11.4.1.

105. 2003 ABA Guidelines for Counsel, supra note 99, at Guideline 10.7 (emphasis added). Guideline 11.4.1 from the 1989 version became Guideline 10.7 in the 2003 version. The 2003 version of the guideline added two new subsections addressing the lawyer's obligation to examine the defense that was provided to the client in previous phases of the case and the lawyer's duty to ensure that the official record is complete. Id.

106. Id. at Guideline 10.7 commentary.

107. See Gregg v. Georgia, 428 U.S. 153, 188 (1976) (plurality opinion of Stewart, Powell \& Stevens, JJ.) (recognizing "that the penalty of death is different in kind from any other punishment imposed under our system of criminal justice"); see also Gardner v. Florida, 430 U.S. 349, 357-358 (1977) (Stevens, J., plurality opinion).

From the point of view of the defendant, [the death penalty] is different in both its severity and its finality. From the point of view of society, the action of the sovereign in taking the life of one of its citizens also differs dramatically from any other legitimate state action. It is of vital importance to the defendant and to the community that any decision to impose the death sentence be, and appear to be, based on reason rather than caprice or emotion. Gardner, 430 U.S. at 357-358 (Stevens, J., plurality opinion). 
guilt/innocence and sentencing phases of all trials, whether they are capital or non-capital cases. The Strickland Court reasoned that the duty to investigate mitigation evidence in a capital case is given such scrutiny because capital sentencing hearings are more like "ordinary trials" than sentencing hearings. Sentencing hearings in death penalty cases, like all trials, call for the effective assistance of counsel to ensure testing in an adversarial process. ${ }^{108}$ Thus, the duty to investigate applies to both factual and mitigation investigation. In addition, wrongful convictions based on inadequate investigation at the trial level occur in non-capital as well as capital cases, with consequences ranging from long prison sentences to serious collateral penalties, such as mandatory deportation of a lawful permanent resident based on one relatively minor conviction. ${ }^{109}$

As one commentator has noted, "[b]ecause most exonerations have not resulted in written legal opinions, their impact is only slowly seeping into case law." 110 The death penalty debate is surely in the undercurrents of the Court's treatment of defense counsel's duty to investigate potential mitigation evidence. The Wiggins Court's decision to grant relief is so significant because Wiggins's attorneys actually did far more investigation than the attorney did in Strickland. This signals a clear move towards greater scrutiny of failures to investigate, driven by evolving standards for investigation that are responsive to the role that adequate investigation is given in the death penalty debate.

If adequate investigations help ensure against wrongful conviction-which is, after all, the central purpose of our criminal justice system, along with the related goal of conviction of the guiltythen how does one best protect against inadequate investigation? The next section explores the role pretrial discovery plays in the

108. See Strickland v. Washington, 466 U.S. 668, 686-87 (1984). The reasoning behind both Strickland and Wiggins is that one cannot decide which mitigation evidence to put on unless one investigates mitigation in the first instance. This applies with equal force to fact investigation. Indeed, Justice O'Connor's articulation of the duty to investigate in Strickland does not even mention the word "mitigation":

[S]trategic choices made after thorough investigation of law and facts rele-

vant to plausible options are virtually unchallengeable; and strategic choices made after less than complete investigation are reasonable precisely to the extent that reasonable professional judgments support the limitations on investigation. In other words, counsel has a duty to make reasonable investigations or to make a reasonable decision that makes particular investigations unnecessary.

Id. at $690-91$.

109. See, e.g., Immigration \& Nationality Act, 8 U.S.C. $\$ ~ 1101-1537$ (2000).

110. Adele Bernhard, Exonerations Change Judicial Views on Ineffective Assistance of Counsel, CRIM. JusT., Fall 2003, at 37. 
fulfillment of such goals. It discusses the link between the duty to investigate and discovery, and concludes that the Constitution does not allow the state to create inadequate investigation by rule.

\section{The Link Between the Duty to Investigate AND Discovery}

A right to effective assistance of counsel that truly recognizes the duty to investigate rings hollow without access to discovery. There are of course enormous systemic and practical obstacles to attaining the goal of appropriate investigation in every case, with lack of funding and high caseloads chief amongst them. ${ }^{111}$ Yet broad early

111. These obstacles are the source of a well-developed body of scholarship. See, e.g., Richard Klein, Emperor Gideon Has No Clothes: The Empty Promise of the Constitutional Right to Effective Assistance of Counsel, 13 Hastings Const. L.Q. 625, 656-57 (1986) (citing, in a section devoted to the "Underfunding of Defender Offices and the Resulting Inadequate Representation by Counsel," a study finding that "[r]elatively few indigent defendants have the benefit of investigation and other expert assistance in their defense. Their advocates are overburdened, undertrained, and underpaid"); Douglas W. Vick, Poorhouse Justice: Underfunded Indigent Defense Services and Arbitrary Death Sentences, 43 BufF. L. REv. 329, 397-410 (1995) (discussing lack of meaningful assistance of counsel in capital litigation); Rebecca Marcus, Note, Racism in Our Courts: The Underfunding of Public Defenders and Its Disproportionate Impact Upon Racial Minorities, 22 Hastings Const. L. Q. 219, 219 (1994) (noting how "[y]ears of consistently severe underfunding, increased caseloads and inadequate resources have created a serious crisis in this nation's public defender system"); Note, Gideon's Promise Unfulfilled: The Need for Litigated Reform of Indigent Defense, 113 Harv. L. Rev. 2062 (2000); see also Wayne J. Lee, Indigent Defense-A Failed Promise, LA. BAR J., Oct.-Nov. 2003, at 174-75 [hereinafter Lee, Indigent Defense] (noting that in random sampling of 172 files from one Louisiana Public Defender's Office, only two contained investigative memos).

Defense counsel who are overwhelmed with cases and lack funds to hire investigators may not benefit from broad, early discovery in the way that private counsel or a relatively well-funded defender office might. Still, even in resource-poor situations, such discovery will make an enormous difference to the ability to make more informed decisions about plea offers because counsel will be able to consider the prosecution's likely case. See, e.g., Laura Berend, Less Reliable Preliminary Hearings \& Plea Bargains in Criminal Cases in California: Discovery Before and After Proposition 115, 48 АM. U. L. REv. 465, 523-24 (1998). In an insightful article, Professor Berend focuses on a specific California proposition which has "dramatically alter[ed] the discovery process in criminal cases," id. at 467 , but explores important issues that apply to discovery nationally. She notes that "[c]ourts rely on the effective assistance of counsel to ensure that guilty pleas are constitutionally acceptable, whether or not discovery supporting a prosecutor's burden of proof has been provided to the defense. Without access to discovery, however, that assistance has little meaning." Id. at 52324.

While in no way underestimating the significance of these other institutional obstacles to the delivery of effective assistance of counsel, this article focuses on the role of discovery in the investigatory process because this link to the Sixth Amendment right has not been well-explored in the literature or the case law and because discovery is such a critical component in the ability to investigate. 
discovery offers great potential for the advancement of better defense investigation with few, if any, downsides. ${ }^{112}$ Moreover, failure to extend such discovery is a governmentally-imposed obstacle to investigation in situations where the accused simply does not have the necessary information or is unable to share it with the attorney due, for example, to mental illness. ${ }^{113}$

There are five sources of authority for pretrial discovery: 1) statutes; ${ }^{114}$ 2) court rules; ${ }^{115}$ 3) the judiciary's "inherent power to grant discovery when necessary to achieve justice";116 4) the common law; ${ }^{117}$ and 5) the Constitution. ${ }^{118}$ In almost all jurisdictions, court rule or statute governs discovery in criminal cases. These rules set out the procedure, including the timing, of the discovery process and determine which items are subject to discovery. ${ }^{119}$ The different states, and the federal system, vary widely in their approaches to discovery rules. At one end of the spectrum are jurisdictions that follow the highly restrictive federal discovery rules; these jurisdictions number around twelve. ${ }^{120}$ New York is one such jurisdiction. At the other end are the slightly larger number of jurisdictions following the broad 1970 American Bar Association Standards. ${ }^{121}$ Around half of the states fall in the middle of the spectrum. ${ }^{122}$

The differences between the Federal and ABA models can be seen in their treatment of discovery of witness lists, information

112. See infra Part III, on why arguments against broad, early discovery lack validity.

113. See supra note 24 and accompanying text, describing other reasons why a defendant might be unwilling or unable to share information with his lawyer.

114. N.Y. Crim. Proc. Law Art. 240 (McKinney 2002).

115. Fed. R. CRIM. P. 16.

116. Traynor, supra note 5, at 231 (citing Palermo v. United States, 360 U.S. 343, 345 (1959) (dictum)). This article does not examine the court's inherent supervisory power to order discovery as such power is "all too rarely exercised." Id. In addition, courts exercise supervisory power only in specific cases and under specific circumstances. Thus, while it is certainly an important power that should be used more than it is to correct particular problems, it does not offer a consistent model for pretrial discovery.

117. See LAFAVE, supra note $8, \S 20.2($ a), at 915 ("Today, common law jurisdictions have all but disappeared").

118. See, e.g., Brady v. Maryland, 373 U.S. 83, 87 (1963); see also infra Part II.B, noting the constitutional sources for access to information.

119. LAFAvE, supra note $8, \S 20.2$ (b), at $915-16$.

120. Id. at 916.

121. Id; see Standards Relating to Discovery, supra note 8, at 1 (noting that "[t]his report proposes more permissive discovery practices for criminal cases than is provided by applicable law in any jurisdiction in the United States").

122. LAFAVE, supra note $8, \S 20.2$ (b), at 916. 
that is critical to defense counsel's ability to investigate. States that follow the ABA model generally require that the prosecution disclose to the defense both names and addresses of witnesses that the state intends to call. ${ }^{123}$ Thus, a number of "sizeable states with one or more large urban centers-e.g., California, Florida, Illinois, Michigan, New Jersey, and Pennsylvania-have broader criminal discovery rules than New York, particularly with regard to disclosure of prosecution witness lists."124 Florida even allows defense counsel to depose certain prosecution witnesses. ${ }^{125}$ In contrast, the current federal rules do not allow for discovery of witness names and the restrictive discovery states follow this model. ${ }^{126}$ There are thus a significant minority of jurisdictions in which restrictive dis-

123. Id. \& 20.3(h), at 925; see also 1990 Brennan, supra note 5, at 10-11.

Fourteen states, for example, allow the defendant access to prosecution witness statements as of right prior to trial, and another eight permit such access at the court's discretion-rules considerably more liberal than the [federal discovery rules]. Others require pretrial disclosure by the prosecution of relevant recorded statement not just of its witnesses, but of any person. Many states require the prosecution to disclose in advance a list of persons it intends to call as witnesses. And a few states permit discovery depositions, either as of right or upon a showing of need.

1990 Brennan, supra note 5, at 10-11.

124. Lawrence K. Marks et al, New York Pretrial Criminal Procedure 407 (1996) (citing "Criminal Discovery in New York," A Report to the New York State Assembly Codes Committee (1992)). As early as 1976, fifteen states failed to require discovery of prosecution witnesses; of the ten most populous states, only New York and Massachusetts were among the fifteen. Pretrial Discovery in Criminal Cases: A Study (Report of the City Bar Committee) [Part 1], N.Y. L.J., Jul. 6, 1976, at 1 [hereinafter Pretrial Discovery I]. At that same time, Alaska, Florida, New Jersey, and Vermont required the prosecution to turn over names of all people with relevant information about the case, including people the prosecution did not plan to call at trial. Pretrial Discovery in Criminal Cases: A Study (Report of the City Bar Committee) [Part 2], N.Y. L.J., Jul. 7, 1976, at 1 (citing Alaska R. CRiM. P. 16(b)(1)(A)(i); Fla. R. Crim. P. 3.220(a)(1)(i); N.J. Ct. R. 3:13-3(9)(7); VT. R. CRIM. P. 16(a)(1)).

125. See Fla. R. CRIM. P. $\$ 3.220$ (h) (2003).

126. In 1975 , Congress rejected an amendment to the federal rules that would have mandated witness list disclosure. See 48 F.R.D. 547, 589-90 (1970) (proposing, in preliminary draft of amendments to Federal Rules of Criminal Procedure, that "[u]pon motion of the defendant the court may order the attorney for the government to furnish to the defendant a written list of the names and addresses of all government witnesses which the attorney for the government intends to call at the trial," absent certification from the government "that to do so may subject the witness or others to physical or substantial economic harm or coercion"); Clennon, supra note 16, at 653 (describing Advisory Committee on Criminal Rules' failed attempt to grant right to pretrial discovery of the names and addresses of government witnesses, an amendment that would have "represented perhaps the most significant expansion of federal criminal discovery in a generation"). 
covery is the rule, and has remained the rule, despite decades of successful experience with broad discovery in other jurisdictions. ${ }^{127}$

Part A of this section examines the discovery process in New York State both generally and through the practical example of the Jane Smith case which was briefly described in the Introduction. This close examination of the late and paltry amount of discovery in New York serves to illustrate the clash between the Sixth Amendment duty to investigate and restrictive discovery rules. Part B of this section will take a brief look at the existing constitutional bases for access to information, which are basically limited to a defendant's right to material, exculpatory evidence in the possession of the prosecution.

\section{A. Too Little, Too Late: A Case Study of New York's Restrictive Discovery Statute}

In New York State, discovery is governed largely by Article 240 of the Criminal Procedure Law. ${ }^{128}$ In order to appreciate the central role this discovery statute plays in defense counsel's access to information, it is crucial to recognize the lack of opportunities for such access outside of the statute in New York. To take two examples, preliminary hearings and voluntary disclosure by the prosecutor are often cited as, and can in certain circumstances constitute, important alternative sources for access to information.

Preliminary hearings can provide "a fairly detailed look at much of the state's case." ${ }^{29}$ New York prosecutors, however, generally

127. See Clennon, supra note 16, at 655-62 (discussing "Expansion of Criminal Discovery at the State Level: The Trend Toward Disclosure of Witness Lists" and noting how twenty-eight states grant defendants pretrial disclosure of names of witnesses the prosecutor expects to call at trial).

128. N.Y. Crim. Proc. Law Art. 240 (McKinney 2002).

129. Rodney J. Uphoff, Criminal Discovery in Oklahoma: A Call for Legislative Action, 46 OKLA. L. Rev. 381, 382-3 (1993) (describing discovery in Oklahoma); see also Steve Schulhofer, Effective Assistance On The Assembly Line, 14 N.Y.U. REv. L. \& Soc. Change 137, 146 (1986) ("In felony cases, Philadelphia defenders prepare very thoroughly. They rely on a client interview and the transcript of the preliminary hearing to determine what investigation is required ...."). But see LAFAvE, supra note $8, \S 14.1(\mathrm{~h})$, at 705 (noting that the extent of discovery through preliminary hearing depends on several factors, including whether hearsay is allowed, the standard of evidence required for bindover, the general practice with respect to how much evidence is offered, limits on the defendant's ability to cross-examine witnesses, what discovery is available for the hearing, and whether the defendant makes the tactical decision to use his subpoena and cross-examination rights for discovery). "In many jurisdictions, these factors combine to provide preliminary hearing discovery that is of quite limited use." Id. 
avoid preliminary hearings, ${ }^{130}$ and instead use the grand jury process. This is a secret proceeding closed to the defendant and defense counsel except for a defendant's opportunity to offer a statement, should he so choose, which would then subject the defendant to cross examination. ${ }^{131}$ In the majority of New York cases, informal opportunities for discovery at the preliminary hearing stage simply do not exist. ${ }^{132}$

Another potential source of access to information is the prosecutor's voluntary disclosure of information beyond, or perhaps earlier, than required by statute. While it is true that a fair number of prosecutors voluntary disclose information in a variety of jurisdictions and circumstances, this is unpredictable and certainly not evenly applied. For example, Manhattan prosecutors follow the restrictive statute rather closely, while across the East River in Brooklyn, prosecutors voluntarily offer open file discovery. ${ }^{133}$

Even if there is access to information through pretrial proceedings or voluntary disclosure, these sources cannot replace the discovery statute in consistently providing the necessary tools to fulfill

130. See New York Criminal Practice 86 (Lawrence N. Gray et al. eds., 2d ed. 1998) [hereinafter Gray, Criminal Practice] (noting that prosecutors try to avoid preliminary hearings as a general matter).

131. See N.Y. Crim. Proc. Art. 190 (Mckinney 2004) ("The Grand Jury and its Proceedings"). In New York, the prosecutor must secure an indictment from a grand jury, even if a preliminary hearing precedes it. See People v. Iannone, 384 N.E.2d 656, $660 \mathrm{n} .3$ (N.Y. 1978) ("The right to indictment by a Grand Jury in New York is dependent solely upon our State Constitution, since the Grand Jury provision contained in the Fifth Amendment to the Federal Constitution is not applicable to the States" (citing Hurtado v. California, 110 U.S. $516(1884)$ )). The only exception to the New York State grand jury indictment requirement is if the defendant waives indictment and consents to be prosecuted by written accusation of the district attorney. See N.Y. Const. art. I, § 6; see also N.Y. CRIM. Proc. LaW § 195.10 (Mckinney 2004) (waiver of indictment). Once the grand jury indicts, a defendant has no right to a preliminary hearing since the purpose of both is to determine that there is reasonable cause to hold and prosecute a defendant. Vega v. Bell, 393 N.E.2d 450, 454 (N.Y. 1979) ("Once the Grand Jury does act, the determination whether there exist [sic] reasonable cause to hold and prosecute a defendant has been made by the Grand Jury itself, the body constitutionally authorized to make that decision ... and hence the need for a [preliminary] felony hearing is obviated" (citing N.Y. Const. art. I, § 6)). Thus, prosecutors go directly to the grand jury and rarely use the preliminary hearing process in New York.

132. Even if a defendant were to have a preliminary hearing, there is no right at this stage to any discovery, as the statutory right to discovery attaches only after indictment. N.Y. CRIM. Proc. LAW $\$ 240.20$ (Mckinney 2004). See discussion infra in text accompanying notes 140-45.

133. Copy of Brooklyn District Attorney's office standard open file discovery agreement is on file with author. While the "open file" policy in Brooklyn does not always lead to a true disclosure of all agreed-upon information, the discovery is certainly broader and earlier than discovery in Manhattan. 
the duty to investigate. While preliminary hearings-when they happen-often allow defense counsel some access to information, the information is neither assured nor full. As one New York practice guide notes, in the rare instance that a prosecutor conducts a preliminary hearing, he "will attempt to keep the testimony to an absolute minimum, making out only a 'bare bones' case sufficient to convince the hearing judge to hold the case for grand jury action." 134 With voluntary disclosure, defense counsel may feel constrained from making full and effective use of the disclosed materials, "lest he be cut off from discovery in future cases."135 Thus, "[p]retrial discovery can operate effectively only if it is impartially administered in accord with objective standards free of adversary considerations of trial strategy."136

In short, the ability to investigate is, in large part in certain cases, dependent upon the discovery statute. ${ }^{137}$ In New York and in other

134. Gray, Criminal Practice, supra note 130 , at 86 . Pretrial proceedings were not designed as discovery devices and the fact that they are not intended for use in obtaining discovery is often written into the statute or rule. See, e.g., Cal. Penal CODE $\$ 866$ (b) (West 1985 \& Supp. 2004) (noting a preliminary hearing "shall not be used for purposes of discovery").

135. Traynor, supra note 5, at 237 (citation omitted) (noting that "if a prosecutor bars discovery except when his evidence is so strong that discovery might induce the defendant to plead guilty, he may seriously discriminate against the defendant who is barred from discovering the weakness of the evidence against him"). In noting these drawbacks to voluntary disclosure. it is not the intention of this article to underestimate the importance of such disclosure. Prosecutors, who are charged with respecting and enforcing constitutional rules, may recognize the Sixth Amendment problems that restrictive discovery rules cause. By releasing more information than required by statute, or releasing it earlier than required, a prosecutor may make it possible for defense counsel to fulfill the duty to investigate. The critique here is based on the fact that not all prosecutors offer voluntary disclosure, and thus there is no uniform rule.

136. Id. at 237-38.

137. While New York State judges do have some inherent authority to order discovery, it is limited both by statute and in practice. New York's Criminal Procedure Law gives the trial court discretion to order discovery of certain property not covered under the main scheme, as long as it is "material to the preparation of [the] defense." N.Y. CRIM. Proc. LAw $\S 240.40(1)$ (c) (Mckinney 2004). Such discretionary orders, however, are limited to property "which the people intend to introduce at the trial." Id. In addition, the discovery is reciprocal: if ordered for the defendant, the judge must upon request also order for the prosecution discovery from the defendant of any property "of the same kind or character." $I d$. This may account for the very limited use, in practice, of this subsection of the discovery statute. Judges may also read their discretion quite restrictively. For example, in offering an example of what the statute might mean by "material to the defense," the Practice Commentaries to $\S 240.40$ lists evidence "such as is deemed within defendant's constitutional right of access to evidence." Although constitutionally-mandated evidence is offered only as an example, such a restrictive reading of the term "material" would render discretionary grants duplicative of a defendant's clearly-established constitutional right to exculpatory evidence. See infra text accompanying notes 199-203 (discussing Brady v. Maryland). It 
jurisdictions where access to information is similarly restricted, the right to effective assistance of counsel is closely linked to the discovery statute and it is critical to scrutinize that statute in light of the Sixth Amendment.

Shortly after the passage of the latest major amendments to Article 240 in 1979, the New York Court of Appeals painted a rather rosy picture of the potentials of the new law, stating that it:

[E]vinces a legislative determination that the trial of a criminal charge should not be a sporting event where each side remains ignorant of facts in the hands of the adversary until events unfold at trial. Broader pretrial discovery enables the defendant to make a more informed plea decision, minimizes the tactical and often unfair advantage to one side, and increases to some degree the opportunity for an accurate determination of guilt or innocence .... In short, pretrial discovery by the defense and prosecution contributes substantially to the fair and effective administration of justice. ${ }^{138}$

Unfortunately, under New York's discovery statute, the defense remains quite ignorant of the prosecution's case until events unfold at trial. ${ }^{139}$

would also be duplicative of other sections of Article 240. See $\S 240.20$ (h) (stating that the prosecutor must disclose anything required "pursuant to the constitution of this state or of the United States"); $\$ 240.40$ (a) (court must order discovery of any material not disclosed under $\$ 240.20$, upon a finding that refusal to comply with $\S 240.20$ is not justified).

In addition to this limited supervisory power, there are also a number of New York State common law rules governing discovery. Many of these, however, have been codified. See, e.g., People v. Rosario, 173 N.E.2d 881, 884 (N.Y. 1961) (codified in $\$ 240.45$ ). In short, it is the statute itself, Article 240 , which is the central source governing discovery in New York.

138. People v. Copicotto, 406 N.E.2d 465, 226 (N.Y. 1980) (citation omitted). In New York, the defendant also has a right to demand a Bill of Particulars to learn factual information that is not included in the indictment. See N.Y. Crim. Proc. Law $\S 200.95$ (1)(a) (Mckinney 2004). This does not, however, include "matters of evidence relating to how the people intend to prove the elements of the offense charged or how the people intend to prove any item of factual information included in the bill of particulars." Id. In this author's practice experience, demands for bills of particulars rarely, if ever, garnered information beyond that contained in the complaint and indictment. For this reason, and because the bill of particulars is not truly a discovery device but rather serves to give the defendant further notice of the charges, see id., this article focuses on Article 240 of the New York Criminal Procedure Law.

139. The New York statute is based on Federal Rule of Criminal Procedure 16, which is considered to be one of the most restrictive discovery rules in the country. Two major differences between the federal and New York State discovery rules are, first, under federal law, the defense can get a trial witness's prior statement only after she has testified and only upon demand. 18 U.S.C. $\$ 3500$ (A) (2000). Under the New York statute, these statements are available after jury selection and before the prosecution's opening statement. N.Y.Crim. Proc. Law \$ 240.45(1). Second, the federal 


\section{Under Article 240 the right to discovery attaches only after the} filing of an indictment in felonies or an "information" (the document upon which a misdemeanor prosecution can proceed) in misdemeanors. ${ }^{140}$ Thus, there is no right to discovery between arrest and the filing of the indictment or information. With misdemeanors, this can mean a period of up to ninety days after the defendant first appears in court with no possibility of discovery. ${ }^{141}$ For felonies, this period can stretch to six months. ${ }^{142}$

The period after arrest, particularly when the arrest is made shortly after the incident at issue, is critical to the investigatory process. As Justice Brennan said:

What assigned counsel obviously needs to discharge the heavy responsibility we give him is at least the opportunity to do what the state does when the trail is fresh, namely, seeking corroboration of the accused's story, or lack of it, from external facts

rule limits such discovery to prior statements reduced to writing that are signed, approved or adopted by the witness. FED. R. CRIM. P. 26.2 (f)(1). In New York, such adoption is not required, so that an investigator's notes of a conversation with the witness are discoverable. See People v. Consolazio, 354 N.E.2d 801, 804-05 (N.Y. 1976).

140. $§ 240.20(1)$; see also N.Y. Crim. Proc. Law $\$ 100.10$ (Mckinney 2004) (defining "information" and other local criminal court accusatory instruments); Hynes v. Cirigliano, 579 N.Y.S.2d 171, 171-72 (App. Div. 1992) (trial court exceeded its authority in ordering discovery where felony complaint was filed but indictment had yet to be filed, since statute only allows for discovery after indictment). The Second Department has found that this rule applies even in a capital case. See Brown v. Appelman, 672 N.Y.S.2d 373, 375 (App. Div. 1998) (denying pre-indictment request for discovery). Indeed, one lower court applied the rule to exculpatory evidence, holding that a defendant who was arrested but not yet indicted for a homicide had no statutory or constitutional right to obtain a videotape of the crime, one that allegedly showed two other men committing the crime. People v. Anthony Gervais, 756 N.Y.S.2d 390, $396-$ 97 (Crim. Ct. 2003).

141. This is because the prosecution has ninety days under New York's speedy trial statute to convert the accusatory instrument used at the initial arraignment into the "information" necessary to proceed to trial on a misdemeanor. N.Y. CRIM. Proc. LAw \& 30.30(1)(b) (Mckinney 2004) (setting out speedy trial period for misdemeanors that are punishable by more than three months in jail). In the case of misdemeanors that are punishable by no more than three months in jail, the speedy trial period is sixty days. $\$ 30.30(1)(c)$.

142. $\$ 30.30(1)(a)$ (setting out speedy trial period for felonies). In practice, felonies are often indicted shortly after the initial court appearance because a court must release an incarcerated defendant who is not indicted within five or six days on his own recognizance. N.Y. CRIM. Proc. $\$ 180.80$ (Mckinney 2004) (release of defendant from custody upon failure of timely disposition). This shorter time period may also happen with incarcerated defendants on misdemeanors, where the prosecutor has five days in which to file an "information" to avoid release of the defendant from custody. N.Y. CRIM. Proc. LAW $\$ 170.70$ (Mckinney 2004). Still, as discussed infra in text accompanying notes $154-165$, a defendant can receive only very limited discovery in the period between the filing of the indictment or information and pretrial hearings. 
through avenues of inquiry opened by what the state has learned. ${ }^{143}$

This period is also critical in a system that relies so heavily on plea bargaining and in which less than one percent of misdemeanors, and five percent of felonies, go to trial. ${ }^{144}$ In New York, a prosecutor can offer a plea bargain prior to filing an indictment or information. If the defendant accepts the offer, the right to discovery has yet to attach when he enters the plea. ${ }^{145}$

Once an indictment or information is filed, discovery occurs in three stages: 1) after filing of the indictment or information; 2) at the pretrial hearing; and 3) at the trial. In fact, under New York's discovery statute, a defendant is entitled to very little pretrial discovery that advances the goal of investigation. Perhaps most importantly, there is no statutory mechanism for discovery of the names of likely prosecution witnesses. ${ }^{146}$ While defense counsel might learn some of the names upon receiving discovery of the pretrial statements of intended trial witnesses, the prosecutor is not obligated to turn these names over until after the jury is sworn. ${ }^{147}$ In addition, there is no right to either the names or statements of

143. 1963 Brennan, supra note 5, at 287 (emphasis added). He was of course thinking more along the lines of fairness in the process and not a constitutional right, but the norms with which we evaluate the Sixth Amendment right to effective assistance of counsel have changed since that 1963 statement. Notably, the Supreme Court decided Gideon v. Wainwright, 372 U.S. 335 (1963), just days after Justice Brennan's lecture.

144. Of the 52,711 felony arrests in New York State in 2002 that led to indictments, only 2,681 defendants were convicted or acquitted at trial; of that same number of arrestees, 45,878 pled guilty to some charge. See N. Y. State Div. of Criminal Justice Services, Disposition of Felony Arrests: New York State (2004), at http://criminaljustice.state.n y.us/crimnet/ojsa/dispos/nys.htm. Of the 345,012 people prosecuted for misdemeanors in lower courts in 1999 in New York State, only 2,499 were convicted or acquitted at trial. N. Y. State Div. of Criminal. Justice Services, 1999 Crime \& Justice AnNual RePORT (2001), at http:/criminaljustice.state.ny.us/crimnet/ojs a/cja_99/sec3/disp-misd.htm.

145. But see Trial Manual 5, supra note $16, \S 182$ (advising defense counsel to complete an investigation even before the arraignment as pleas are often offered at this stage, and noting "the need to be knowledgeable in bargaining").

146. See People v. Miller, 484 N.Y.S.2d 183, 184 (App. Div. 1984) (finding that "[t]here is neither a constitutional nor statutory obligation mandating the pretrial disclosure of the identity of a prosecution witness"). The Miller court noted that disclosure of prosecution witness identity was in the trial court's discretion. Id. (citing People v. Lynch, 23 N.Y.2d 262 (1968)). The Court, however, went on to hold that "simply assert[ing that] disclosure was necessary to prepare for trial" did not constitute the type of "special circumstances" that a defendant must show to prove abuse of discretion in denial of such disclosure. Id. at 185.

147. N.Y. Crim. Proc. LaW $\S 240.45$ (Mckinney 2004). For witnesses at any pretrial hearing, the prosecution is not obligated to turn over relevant statements until after their direct testimony. $\$ 240.44$. 
witnesses with information relevant to the case that the prosecution does not call at the hearing or trial, unless they constitute material, exculpatory evidence. ${ }^{148}$

The remainder of this section will return to the case of Jane Smith mentioned in the Introduction and will walk through the discovery process, highlighting two perspectives from which to consider the availability of discovery under the New York statute: substance and timing. ${ }^{149}$ The article will describe what information a defendant gets, does not get, and when she gets it under the statute. ${ }^{150}$

Put yourself back into the shoes of the Legal Aid Society, Criminal Defense Division attorney in New York County Criminal Court, who is representing Jane Smith. ${ }^{151}$ As noted in the Introduction, all you know from the arraignment file is that your client is charged with Grand Larceny, accused by "a person known to the District Attorney's office" of stealing \$3,500 some three months ago near the corner of Third Avenue and Twenty-third Street. ${ }^{152}$ Your arraignment interview of Ms. Smith, a woman in her midfifties, is brief for two reasons. First, Ms. Smith is innocent. She cannot tell you anything about the charges other than to say she was probably getting free lunch at a soup kitchen around 1 p.m. but she is not sure because the date of the alleged crime is almost three months ago. She does not remember the name of the soup kitchen but gives you an approximate address and tells you she can take you there. Second, she does not trust you, and you certainly cannot gain her confidence with your knowledge of the case; you do not know anything about the charges other than those couple of sentences on that one piece of paper in that file.

148. See infra note 163 and accompanying text which discusses New York's codification of the rule in Brady v. Maryland.

149. This article will not focus on all of the details of Article 240. For a comprehensive discussion, see MARKS ET AL., supra note 124, at Chapter Seven.

150. Article 240 also provides for discovery from the defense, although as noted infra at note 186, this article focuses only on the Sixth Amendment implications for discovery from the prosecution for the defense.

151. Criminal Court is New York City's lower court for criminal matters, and has jurisdiction over misdemeanors at all stages and over felonies only until the prosecution files a grand jury indictment. Thus, almost all defendants are initially arraigned in Criminal Court, on cases ranging from jumping the turnstile to capital murder. Supreme Court has jurisdiction over charges indicted by a grand jury. If a defendant is indicted, the defendant is then arraigned in Supreme Court on that indictment. See 31 N.Y. JuRis 2D Crim. Law 235-37 (1995).

152. See copy of sample Criminal Court Complaint that fails to name complaining witness on file with author. 
You tell the arraignment prosecutor that you are troubled about the case and ask her to tell you something other than what is in the Complaint (the name of the complainant, how the alleged theft took place, the exact location where it happened), so you can look into the charges further. The arraignment prosecutor is unwilling to share any other information and the discovery statute does not require disclosure: as noted above, Article 240 applies only to felonies that have been indicted. ${ }^{153}$ The judge sets $\$ 1,000$ bail in Ms. Smith's case. Five days later, the grand jury indicts Ms. Smith and she continues to be held on $\$ 1,000$ bail. You have no idea who the complainant is; your investigator is still searching for the soup kitchen.

Two weeks after being indicted by the grand jury, your client is arraigned on the indictment in Supreme Court. You may now seek discovery directly from the prosecution under the statute. In response to your discovery request, the prosecutor informs you that you already have notice of the date, time, and place of the offense and arrest, ${ }^{154}$ and that none of the other items on the discovery-bydemand list apply. ${ }^{155}$ Ms. Smith did not make a statement, ${ }^{156}$ nor did she testify in the grand jury; ${ }^{157}$ there were no written reports of scientific tests or medical examinations; ${ }^{158}$ no photographs taken or drawings made, other than Ms. Smith's arrest photo (and you can

153. See supra note 140 and accompanying text.

154. See N.Y. Crim. Proc. Law $\$ 240.20$ (1)(i) (McKinney 2004) (granting a right to the "approximate date, time and place of the offense charged and of defendant's arrest").

155. See $\S 240.20$. The prosecutor has fifteen days to comply or refuse to comply with defendant's demand, with extensions for "good cause." \$240.80 (2) (governing timing of demand discovery). A major change to Article 240 in 1979 was that a defendant no longer had to file a motion with the court requesting these items but could seek them by written demand directly from the prosecutor. Id. commentary at 334 . If a prosecutor refuses to comply with the demand, the defendant can then move for a court order of compliance with the original demand. See $\S 240.40$.

156. $\$ 240.20(1)(a)$, granting a right to:

"[a]ny written, recorded or oral statement of the defendant, and of a codefendant to be tried jointly, made, other than in the course of the criminal transaction, to a public servant engaged in law enforcement activity or to a person then acting under his direction or in cooperation with him." Id.

157. $\S 240.20(1)(b)$ (granting a right to the statement by the defendant, or any codefendant to be tried jointly with the defendant, before any grand jury).

158. $\$ 240.20(1)$ (c) (granting a right to any written report on physical or mental examination, or scientific test or experiment relating to criminal action, but only if the prosecution intends to introduce it at trial or if it was made by or at request of law enforcement or by a person the prosecutor intends to call at trial). 
look at that) $;^{159}$ no property released back to its owner; ${ }^{160}$ no property taken from Ms. Smith; ${ }^{161}$ no electronic recordings the prosecutor will use at trial, as the complainant walked into the precinct to report the crime; ${ }^{162}$ and, finally, there is-according to the prosecutor, who has sole responsibility for deciding this issue at this stage-no material exculpatory evidence. ${ }^{163}$

Notably absent from this post-indictment/pre-pretrial hearing list of discoverable material are any police reports with witness statements or names and addresses of prosecution witnesses. ${ }^{164}$ For Ms. Smith, as for many defendants, this stage of discovery is fairly meaningless even though it is called the "heart" of discovery in the Commentary accompanying the statute. ${ }^{165}$ Although you learn that Mary Johnson is the complaining witness, her name is simply too common to be useful in finding her.

Under the current New York discovery statute, the first opportunity for meaningful information that might allow you to begin truly

159. $\$ 240.20(1)(d)$ (granting a right to photographs and drawings relating to the criminal action, but only if the prosecution intends to introduce it at trial or if it was made by or at request of law enforcement or by a person the prosecutor intends to call at trial).

160. $\$ 240.20(1)(\mathrm{e})$ (granting a right to any photograph, photocopy or other reproduction made by or at the direction of the police, a peace officer or the prosecutor, irrespective of whether the prosecutor intends to introduce the property or reproduction at trial).

161. $\S 240.20(1)(f)$ (granting a right to inspect property taken from the defendant or a co-defendant to be tried jointly).

162. $\$ 240.20(1)(\mathrm{g})$ (granting a right to "[a]ny tapes or other electronic recordings which the prosecutor intends to introduce at trial, irrespective of whether such recording was made during the course of the criminal transaction").

163. $\$ 240.20(1)(\mathrm{h})$ (granting a right to "[a]nything required to be disclosed, prior to trial, to the defendant by the prosecutor, pursuant to the constitution of [the State of New York] or of the United States"). This section of the Criminal Procedure Law codifies the constitutional right to material, exculpatory evidence enunciated in Brady v. Maryland. See infra notes 199-203 and accompanying text (discussing Brady doctrine).

164. See supra note 146 (discussing the trial courts' discretionary power to order disclosure of the identity of prosecution witnesses). The absence of a statutory mechanism for disclosure of witness names was not always the case in New York. For fifty years between 1881 and 1936, the prosecutor was required to attach to the indictment the names of prosecution witnesses who appeared in the grand jury. See Pretrial Discovery I, supra note 124, at 6 (citing former Code of Criminal Procedure $\$ 291$ ); see also John F. O'Mara \& D. Bruce Crew, III, Criminal Discovery in New York STATE: SElected Issues 22 n.12 (1976). This discovery statute was repealed in 1936 in order to control a "prolific source of motions to dismiss the indictment." See Pretrial Discovery I, supra note 124, at 6 (quoting New York Commission on the Administration of Justice, Second Supplemental Report, 1936 (Legislation Document 1936, No. 80 at 20)). Until passage of the Criminal Procedure Law in 1971 there was no statutory right to discovery in New York. See id.

165. $\$ 240.20$ commentary at 339 . 
investigating Ms. Smith's case could come at the pretrial hearing. ${ }^{166}$ That hearing usually occurs just before trial. On average, it takes about ten to twelve months after arrest for a felony case to go to trial, although this time period is likely to be significantly shorter for an incarcerated defendant. ${ }^{167}$ At the hearing, the defendant has the right to those portions of written statements of testifying witnesses that relate to the subject matter of their pretrial testimony. ${ }^{168}$ Although the statutory right applies only after the direct testimony of the witness, ${ }^{169}$ the prosecutor in Ms. Smith's case turns over these materials outside the courtroom just before the hearing begins. ${ }^{170}$ For Ms. Smith, there is a short hearing about the

166. See $\$ 240.44$ (governing discovery upon request at the pretrial hearing).

167. See Statistical table compiled by Dean Mauro, New York State Division of Criminal Justice Services, Statistical Services Unit (May 10, 2004) (on file with author) (listing 324.5 as the median number of days from arrest to guilty verdict for New York State defendants convicted of felonies and sentenced to prison or jail time in 2003, and a 351-day median for New York State defendants acquitted in felony trials in 2003; for New York City, the medians are 359 for convictions and 378.5 for acquittals). See also Lee, Indigent Defense, supra note 111, at 174 (noting that "[t]he average time from arrest to disposition for felony cases nation-wide is 214 days, with 90 percent of all felony cases resolved within one year of the date of arrest"). These statistics do not separate incarcerated from non-incarcerated defendants but, in the author's experience and based on conversations with Manhattan practitioners, the average time for such cases to get to trial would be about six to eight months.

168. See $\S 240.44(1)$. There is also a right to discover the criminal convictions and existence of pending criminal actions against any pretrial witnesses, to the extent that such information is known to the prosecution or defense. $\S 240.44(2) \&(3)$. These sections apply to both parties, so that the defendant must turn over all covered material if he calls any witnesses at the pretrial hearing. This reciprocity holds true in the section governing discovery for trial witnesses. See $\$ 240.45(2)$. In addition, the prosecutor has a more limited right to discovery upon demand in the period after the filing of the indictment or information. See $\$ 240.30$.

169. See $\S 240.44$ (stating that each party, at the conclusion of direct examination of each of its witnesses, shall upon request of the other party make relevant materials available to that party).

170. In practice, Manhattan prosecutors will usually turn over this discovery material shortly before the hearing begins, at least in low-level felonies and misdemeanors. Interestingly, prosecutors often do voluntarily disclose more information, earlier, in the more serious cases. Judges often pressure prosecutors to turn the material over before the hearing begins, to speed the process. From a systemic viewpoint, it is highly inefficient to have a case ready to go except that defense counsel still has not seen the discovery material. See supra notes 229-230 and accompanying text (discussing efficiency justification for broader discovery). Too often, however, the judge considers the matter settled if defense counsel has some minimal time to simply read over the materials. For example, in a "buy and bust" drug case, where the paperwork is fairly uniform across cases, judges often express the view that defense counsel can read the material over quickly and then return to it after the witness testifies. Judges sometimes tell defense counsel that they will allow a re-opening of cross examination if defense counsel discovers anything "meaningful" in the documents, without clarifying the meaning of "meaningful." The problem with this method, of course, is that it 
identification procedure. One police officer testifies and the prosecution redacts the address of the complaining witness on the documents he turns over. You have no right to Mary Johnson's address under the statute. ${ }^{171}$

Immediately after the pretrial hearing, jury selection begins. Under the statute, you have a right to the prior statements and criminal history of trial witnesses after the jury is sworn. ${ }^{172}$ The timing of discovery here is only slightly more generous than the federal statute governing witness statements. Under the Jencks Act, upon defense counsel's request, the government must turn over portions of any prior recorded statements of a government witness that relates to her trial testimony only after she testifies on direct examination. ${ }^{173}$ Courts do not have authority to order pretrial disclosure of such statements. ${ }^{174}$ The Jencks Act is an exception to the Federal Rules of Criminal Procedure prohibiting "the discovery or inspection of ... statements made by prospective gov-

ignores the central role discovery plays in the investigatory function. If defense counsel first learns the name or address of the complainant or other witnesses, or the location from which a police officer watched a drug sale, at the pretrial hearing or just before jury selection, then that might be the first point that counsel could seek to investigate the issue. The request for a mid-hearing or mid-trial adjournment, however, is certainly not granted as a matter of course and-at least in New York County-usually not granted at all. See generally Richard Klein, Relationship of the Court \& Defense Counsel: The Impact on Competent Representation \& Proposals for Reform, 29 B.C. L. REv. 531, 540-47 (1988) [hereinafter Klein, Competent Representation] (detailing cases in which the court denied requests for continuances despite the fact that defense counsel informed the court that they were unprepared to proceed with trial).

171. See, e.g., People v. Garcia, 616 N.Y.S.2d 501, 502 (App. Div. 1994) (denying defendant's claim of a right to access complaining witness's phone number and address).

172. $§ 240.45$ (b) \& (c); see also $\S 240.43$ (stating that immediately before jury selection the prosecution must, upon demand, inform the defendant of any prior bad but uncharged conduct of the defendant that the prosecutor intends to use at trial).

173. 18 U.S.C. $\$ 3500$ (2000). This is commonly known as "The Jencks Act," because Congress passed it in response to the Supreme Court's decision in Jencks $v$. United States, 353 U.S. 657, 668 (1957) (holding that government must turn over all reports of two government witnesses relating to events and activities to which they testified at trial).

174. See, e.g., United States v. Sebastian, 497 F.2d 1267, 1270 (2d Cir. 1974) (holding that district judge cannot compel government to turn over Jencks Act materials until after direct examination of the relevant witness, but noting that the court "encourage[s] th[e] practice [of earlier, voluntary discovery] and believe[s] that it frequently benefits not only a defendant, but the Government too, and that it may also serve[s] the public interest in expediting the fair resolution of criminal cases"); see also United States v. Steurer, 942 F. Supp. 1183, 1190 (N.D. Ill. 1996) (holding that "a defendant does not have a right to pretrial disclosure of Jencks material under the Jencks Act. A district court may only order disclosure of such material after a witness called by the government has testified on direct examination at trial"). 
ernment witnesses."175 Taken together, the Federal Rules of Criminal Procedure and the Jencks Act are designed to ensure that witness statements are available for impeachment purposes but not to assist in defense counsel's investigation. This is, in essence, the situation in New York.

This time, the judge in Ms. Smith's case rejects the prosecution's attempt to redact the address of the complainant. But now you are in the middle of a trial and the judge also rejects your request for an adjournment. ${ }^{176}$ You get a message to Ms. Johnson to please call you. You visit her apartment that evening-when you should be working on your upcoming cross-examinations of the remaining prosecution witnesses, whose prior statements you have just received-but she is not home. The next morning, Ms. Johnson testifies as the main prosecution witness. Her direct testimony is brief: she describes how she withdrew $\$ 3,500$ from her bank and gave it to Ms. Smith for a supposed joint enterprise that Ms. Smith proposed to her after introducing herself to Ms. Johnson on a street corner. Ms. Johnson testifies that Ms. Smith took the money and never returned. You are careful in your cross examination because you believe that the best argument you have on summation-combined with the somewhat shaky alibi evidence, described just below, that you were able to obtain-is that a jury should not rely, beyond a reasonable doubt, on the identification abilities of anyone who would hand $\$ 3,500$ to a complete stranger.

The timing of the release of Ms. Johnson's name and addresstiming which made it impossible to contact her before she took the stand-highlights a significant problem with discovery that comes so late in the process: "[C]ross-examination, one of the most effective tools available to test the reliability of information, is effective only to the degree that the cross-examining party has access to relevant information and sufficient time with which to prepare to use it." 177 In addition, if the prosecutor disclosed information earlier in

175. FED. R. CRIM. P. 16(a)(2); see also Rule 26.2(g) (allowing for inspection of those portions of prior recorded statements of witness that relate to their testimony at suppression, preliminary and several other types of hearings after direct testimony of the witness at the hearing). Rule 26.2 applies to both sides, so that the defendant must produce relevant recorded statements for any witnesses he calls at such hearings. R. 26.2(a) .

176. Due to enormous pressure upon trial courts to move their calendars, requests for continuances are routinely denied. See Klein, Competent Representation, supra note 170 , at $540-47$.

177. Berend, supra note 111, at 472 (emphasis added). The problems go deeper than just those associated with cross-examination. California Supreme Court Justice Roger Traynor, criticizing the restrictive federal discovery rule in 1964 for its lack of a 
the case, it could generate important investigative leads that defense counsel might pursue.

About ninety-five percent of criminal cases end not with trials, but in plea bargains. ${ }^{178}$ The claim of this article, that broad and early discovery is necessary for the effective assistance of counsel, applies with even more force to plea bargains because, in the plea bargain context, inadequate investigation is even more widespread and harder to detect. ${ }^{179}$ This problem is rarely highlighted in the case law, as many guilty pleas are never appealed and appeals that do occur are often rejected under the stringent standards governing the validity of plea bargains. ${ }^{180}$ Certainly, there is a strong need for information about the prosecution's case and possible defenses in the plea bargain process. ${ }^{181}$

Ms. Smith's trial illustrates the problem of late disclosure of information. During your cross-examination of Ms. Johnson, you ask her about Peter Lee, whose name appears in the police reports. She tells you that Mr. Lee is a friend of hers who arrived as she was waiting, in vain, for Jane Smith to return. He did not see any part of the incident, but he did go to the precinct with Johnson to report the crime. Lee's address does not appear in any of the reports you were given; the judge denies your request for his address and for

mechanism for discovery of names and addresses of witnesses, identified two problems that all trial attorneys have faced:

The defense confronts many witnesses for the first time in the contentious atmosphere of courtroom cross-examination, when the witness has already allied himself with the prosecution and may have rehearsed his testimony with the prosecutor. It is not easy to elicit impartial testimony from a witness under such circumstances. Moreover, the trial may run its course without the defense's ever becoming aware of potential witnesses not called by the prosecution.

Traynor, supra note 5, at 236; see also id. at 235 ("One familiar with the steady development of criminal discovery in his own state [of California] for nearly a decade may be permitted to note that pretrial discovery in the federal courts appears by comparison not only inadequate, but riddled with arbitrary rules").

178. See Criminal Case Proceedings Statistics, at http://www.ojp.usdoj.gov/bjs/ cases.htm (last revised on May 14, 2004) (noting, in summary findings on felony defendants in state courts, that "[n]inety-five percent of convictions occurring within 1 year of arrest were obtained through a guilty plea").

179. See Clennon, supra note 16, at 670-71 ("Because courts require a defendant pleading guilty to admit to the existence of a factual basis for the plea and to forego proof beyond a reasonable doubt, counsel's fact investigation rarely, if ever, comes under scrutiny" (footnotes omitted)); see also supra note 53.

180. See Brady v. United States, 397 U.S. 742, 748 (1970) (stating requirement that guilty pleas are valid if they are knowing, voluntary and intelligent); see also supra note 43 (discussing the stringent standards for showing ineffective assistance where the case ended in a guilty plea).

181. See supra note 111. 
any other police reports relating to him, reasoning that, based on Johnson's testimony, he has no relevant information.

You also learn, when you first see Ms. Johnson, that she is AsianAmerican; your client is African-American. This is significant. This is a one-witness identification case with no other evidence against Ms. Smith and cross-racial identifications have been shown to be particularly unreliable. ${ }^{182}$ The judge denies your request for an adjournment to find an expert witness who can testify about cross-racial identifications.

After the prosecution rests, you present an alibi defense. Your student intern found the soup kitchen a month earlier and someone who worked there knew your client and remembered that she came in quite regularly at 1 p.m. for lunch. Unfortunately, the organization has a policy of discarding the sign-in sheets after one month, so the defense is weak. As soon as you learned this information, you filed with the court and served on the prosecutor a notice of the alibi defense. ${ }^{183}$ The statute governing such notice"the first inroad on the general rule that the defendant did not have to disclose anything before trial" 184 - stands in stark contrast to the prosecution's obligation to disclose information. If a defendant in New York, as is the case in most other jurisdictions, ${ }^{185}$ intends to put on an alibi defense, he must tell the prosecutor not only of this intention, but must also provide the "place or places where the defendant claims to have been at the time in question" as well as "the names, the residential addresses, the places of employment and the addresses thereof of every such alibi witness upon whom he intends to rely."186 Perhaps because the Constitu-

182. See Elizabeth F. Loftus, Eyewitness Testimony 340-41 (3d ed. 1997); see also Radha Natarajan, Note, Racialized Memory \& Reliability: Due Process Applied to Cross-Racial Eyewitness Identifications, 78 N.Y.U. L. REv. 1821, 1822 \& n.7-8 (2003) (citing social science research in support of statement that "[w]hile all eyewitness identifications are prone to error, cross-racial eyewitness identifications are more often wrong than same-race identifications").

183. N.Y. Crim. Proc. Law $§ 250.20$ (1) (McKinney 2002) (stating that upon demand of the prosecutor, defendant must file notice of alibi defense).

184. $\S 250.20$ commentary at 125 .

185. See. e.g., Col. Rev. Stat. § 16-7-102 (2003); GA. Code AnN. § 17-16-5(a) (1997).

186. N.Y. Crim. Proc. LAw $\S 250.20(1)$. In Williams v. Florida, the Court first considered, and upheld, the constitutionality of pretrial discovery for the prosecution. 399 U.S. 78, 82 n.11 (1970) (noting that, "[i]n addition to [the] Florida [rule at issue], at least 15 States appear to have alibi-notice requirements of one sort or another"). This article does not address the issue of discovery for the prosecution, other than to make this comparative point about alibi notice, as the government has no Sixth Amendment rights and thus the analytic framework proposed here does not apply. 
tion requires such reciprocity, ${ }^{187}$ this is the only part of the Criminal Procedure Law of New York State that requires the prosecution to turn over witness names and addresses that the prosecution proposes to offer in rebuttal to the alibi defense, although "[a] witness who will testify that the defendant was at the scene of the crime is not such an alibi rebuttal witness." 188 Discussing a precursor to the current notice of alibi statute, the New York Court of Appeals stated:

The purpose of the statute was to prevent a defendant from obtaining acquittal of a crime of which he was guilty by calling a number of witnesses to testify to a false alibi with no prior opportunity afforded to the District Attorney to make any investigation of them or their story. ${ }^{189}$

In other words, a presumption of guilt (and a subsequent lie to escape the consequences of that guilt), led the court and legislature to conclude that the prosecution must have full disclosure of all relevant information to allow investigation.

The jury deliberates for four hours before convicting Ms. Smith. She had been convicted of felony drug possession eight years prior; consequently, she receives the minimum sentence of two to four years in prison. ${ }^{190}$ During the appeals process, Ms. Smith's appellate attorney again requests and this time receives a police report relating to Peter Lee. It confirms Ms. Johnson's trial testimony that Mr. Lee saw nothing of the incident. As he did not testify, the prosecution was not required to disclose the report at trial. The report lists his address and phone number and the attorney calls him. Mr. Lee confirms that he did not witness the incident but says he spoke with Ms. Johnson about the case, in depth, as it progressed. Ms. Johnson told him that she knew when she saw Ms. Smith's photograph in the precinct photo book that she was the right person because a "vision" came to her and made it all clear. Also, it was hard to be sure about Ms. Smith before the moment of

187. See Wardius v. Oregon, 412 U.S. 470,472 (1973).

188. $§ 250.20(2)$.

189. People v. Rakiec, 45 N.E.2d 812, 813 (N.Y. 1942) (emphasis added); see also People v. Ruiz, 419 N.Y.S.2d 864, 866 (Sup. Ct. 1999) ("The purpose of the alibi statutory scheme is to afford the prosecutor an opportunity to thoroughly investigate the merits of the alibi, for the alibi is one defense which is easy to manufacture"); see also Williams, 399 U.S. at 81 (noting that "[g]iven the ease with which an alibi can be fabricated, the State's interest in protecting itself against an eleventh-hour defense is both obvious and legitimate").

190. See N.Y. Penal LaW $\$ 70.06$ (McKinney 1998) ("Sentence of Imprisonment for Second Felony Offender"). 
the vision because all black women of that age look the same to her. Confronted with Lee's statement, Ms. Johnson confirms it. Although Ms. Smith was already out on parole by this point, her case was eventually dismissed. Ms. Smith spent two years in prison. If there had been early discovery, her case may never have gone to trial. At the very least, it is likely that she would have been released on her own recognizance to await a trial in which defense counsel could have used this critical information to test the reliability of Ms. Johnson's identification of Ms. Smith.

The "Jane Smith" case illustrates how in some cases, including those in which the accused is innocent of and knows nothing about the charges against her, it is nearly impossible to undertake an independent factual investigation into the charges. Given the role the presumption of innocence plays in our criminal justice system, we should assume that the defendant cannot supply the necessary information. ${ }^{191}$ Even if a particular defendant is guilty or just has information relevant to the charges, there are many other potential obstacles to using the defendant as the primary source of information for investigating a case. For example, a defendant might: not know who the witnesses are or where to find them; distrust her lawyer; be incarcerated (and thus unable to lead the attorney to witnesses whose names she does not know); have poor recollection; or suffer from mental health problems. ${ }^{192}$

In Wiggins, the deficient performance prong of the Strickland test asked "whether the investigation supporting counsel's decision not to introduce mitigating evidence of Wiggins's background was itself reasonable." 193 The deficiency question in Jane Smith's case would, in theory, ask whether defense counsel's total failure to investigate the case, other than for alibi purposes, was a reasoned, strategic decision to forgo such investigation. But that cannot be the question in Jane Smith's case-at least not until the wall of restrictive discovery is torn down. Wiggins's and Jane Smith's attorneys faced very different challenges: Wiggins's attorneys had the tools they needed to investigate mitigation at their disposal; Smith's attorney did not. The facts necessary to develop mitigation

191. See 1963 Brennan, supra note 5 , at 287 (noting that "[t]he implication in the argument against discovery is that that accused is guilty," and asking: "is not such denial [of all discovery] blind to the superlatively important public interest in the acquittal of the innocent?").

192. See, e.g., Atkins v. Virginia, 536 U.S. 304, 320 (2002) (acknowledging that "[m]entally retarded defendants may be less able to give meaningful assistance to their counsel"); see also supra note 24.

193. Wiggins v. Smith, 123 U.S. 2527, 2536 (2003). 
evidence for a capital sentencing hearing come largely from sources that are not within the prosecution's control: the defendant, his family, his friends, and his medical, school, foster care, and other records. There was no external obstacle keeping Wiggins's attorneys from investigating these sources; they simply failed to do a competent job in looking into them. ${ }^{194}$

The fact investigation context is quite different. If an attorney cannot get the information she needs to investigate from her client, the question becomes: is the legislative decision to grant only restrictive discovery, late in the case, unconstitutional if it blocks the ability of defense counsel to investigate the facts? In other words, is the discovery statute a state-imposed barrier to the effective assistance of counsel? Part B of this section takes a brief look at the current state of constitutional law governing defense counsel's access to information. Part III asks whether there remain any truly legitimate reasons for restrictive discovery rules.

\section{B. Constitutional Sources for Access to Information}

The Supreme Court has praised the "salutary development" of broad discovery ${ }^{195}$ and noted the fairness-enhancing value in rules that allow "both the defendant and the State ample opportunity to investigate certain facts crucial to the determination of guilt or innocence."196 Despite recognizing "fairness in the adversary system" as a core value of the Due Process Clause,${ }^{197}$ the Court has made it clear that " $[\mathrm{t}]$ here is no general constitutional right to discovery in a criminal case." 198 The Supreme Court has never reviewed a claim that a restrictive discovery rule violates the Sixth Amendment right to effective assistance of counsel.

Under Brady v. Maryland ${ }^{199}$ and related cases, the Due Process Clause mandates only disclosure of exculpatory and impeachment

194. By "no external obstacle," I mean that counsel had the information in front of them and could decide what to do with it. See supra note 21 (noting how Wiggins's attorneys had access to investigatory resources). In some cases, the defendant may suffer from mental illness or other impairments which make it difficult for counsel to obtain mitigation information, see supra notes $24-25$ and accompanying text, or the defendant may be unwilling to have counsel speak with witnesses who might provide mitigation evidence.

195. Wardius v. Oregon, 412 U.S. 470, 474 (1973).

196. Williams v. Florida, 399 U.S. 78, 82 (1970).

197. Wardius, 412 U.S. at 474.

198. Weatherford v. Bursey, 429 U.S. 545, 559 (1977); see also United States v. Ruiz, 536 U.S. 622, 629 (2002) (noting that "the Constitution does not require the prosecutor to share all useful information with the defendant").

199. 373 U.S. 83 (1963). 
evidence within the prosecutor's possession that is material to the outcome of the case. ${ }^{200}$ This is not a right to pretrial discovery but is instead a due process right to access information that is necessary to ensure a fair trial. ${ }^{201}$ The Supreme Court has defined "materiality" stringently: as a reasonable probability that, had the evidence been disclosed, the outcome would have been different. ${ }^{202}$ Thus, while claims of governmental failure to turn over Brady material are common, one study found only 270 federal and state court cases in the last forty years that had resulted in reversal of conviction or a new hearing due to withheld Brady material. ${ }^{203}$

200. Id.; see also Strickler v. Greene, 527 U.S. 263, 281-82 (1999) (listing "three components of a true Brady violation: The evidence at issue must be favorable to the accused, either because it is exculpatory, or because it is impeaching; that evidence must have been suppressed by the state, either willfully or inadvertently; and prejudice must have ensued"); Kyles v. Whitley, 514 U.S. 419, 437 (1995) (noting that, with respect to limitation to disclosure of evidence "within its possession," the government is responsible for "any favorable evidence known to the others acting on the government's behalf in the case, including the police"); United States v. Bagley, 473 U.S. 667,676 (1985) (holding that the prosecution's duty to disclose information encompasses impeachment as well as exculpatory evidence); United States v. Agurs, 427 U.S. 97, 106-07 (1976) (finding Brady duty to disclose exculpatory evidence is applicable even though there has been no request by the accused).

201. See Ruiz, 536 U.S. at 629-31 (describing Brady as a "trial-related" right rather than a right to discovery from the prosecution). With respect to such rights in the plea bargain context, Ruiz held that, although the government must disclose impeachment evidence for use at a trial, disclosure is not required prior to entering a plea bargain with a defendant. Id. at 625. Ruiz did not address the question of whether the same rule would apply to exculpatory evidence. In Ruiz, however, the Court noted that, under the plea agreement at issue in that case, the defendant would have received such exculpatory evidence prior to entering the plea. Id. Certainly, there is an argument to be made that failure to provide exculpatory evidence prior to a plea could mean that the plea fails the constitutional requirements that it be knowing, intelligent and voluntary. Id. at 629 (quoting Brady v. United States, 397 U.S. 742, 748 (2002)). The claim would thus be based in the due process right to a knowing and voluntary plea, rather than in the due process rights relating to fair trials set out in the Brady line of cases. See also LAFAVE, supra note 8, § 24.3(b), at 1107 (noting that the majority of courts examining whether the government must turn over exculpatory evidence prior to a plea bargain have found that there is such a responsibility).

202. Bagley, 473 U.S. at 682 (citing Strickland v. Washington, 466 U.S. 668, 694 (1984)); see also Kyles, 514 U.S. at 433-34.

203. Richard A. Serrano, Withheld Evidence Can Give Convicts New Life, L.A. TImes, May 29, 2001, at A1 (citing the Habeas Assistance and Training Project study); see also Strickler, 527 U.S. at 296 (holding that petitioner satisfied Brady requirements that the prosecution failed to disclose evidence and that the evidence was exculpatory, but denying the claim because petitioner failed to show that there was a reasonable probability that his conviction or sentence would have been different had the materials been disclosed). Given its outcome-oriented materiality requirement, Brady offers prosecutors very little incentive to turn over material. Indeed, the Brady line of cases has been widely criticized as creating a pretrial right to just about nothing at all. See, e.g., Scott E. Sundby, Fallen Superheroes \& Constitutional Mirages: The Tale of Brady v. Maryland, 33 MCGeorge L. Rev. 643, 659 (2002) ("It is important . . to 
The Court has declined to use the Sixth Amendment Confrontation and Compulsory Process Clauses to decide pretrial access-toinformation claims. After noting that it "has had little occasion to discuss the contours of the Compulsory Process Clause,"204 the Court concluded that the clause would in any case provide no greater right to discover favorable information than the Due Process Clause. ${ }^{205}$ A Confrontation Clause challenge to restrictions on the right to discover information garnered a plurality for the proposition that the clause is only "designed to prevent improper restrictions on the types of questions that defense counsel may ask during cross-examination," 206 and would not encompass access to pretrial information. ${ }^{207}$ Rather, according to the plurality, analysis of access to pretrial information properly fell under the well-established due process test found in the Brady line of cases. ${ }^{208}$

The Court recognizes an informational power imbalance within its due process analysis and has found that discovery must generally be a "two-way street," ${ }^{209}$ but it did so in the context of reviewing a rule allowing for discovery for the prosecution from the defense in the form of disclosure of an alibi witness list. ${ }^{210}$ Thus, a state may require such discovery from the defense only if it allows for reciprocal alibi discovery from the prosecution. ${ }^{211}$ This right to

recognize Brady as less of a discovery mechanism and as more of a post-trial due process safety check where information surfaces after trial that exculpatory evidence was suppressed").

204. See Pennsylvania v. Ritchie, 480 U.S. 39, 55 (1987) (noting that, since the Court's holding in United States v. Burr that Burr's compulsory process rights entitled him to serve a subpoena on President Jefferson, "the Compulsory Process Clause rarely was a factor in this Court's decisions during the next 160 years").

205. Id. at 56. For a comprehensive discussion of the Compulsory Process Clause, including potential implications for discovery, see generally Peter Westen, Compulsory Process Clause, 73 Mrch. L. Rev 71 (1974).

206. Ritchie, 480 U.S at 52 (plurality of Chief Justice Rehnquist, and Justices Powell, O'Connor, and White).

207. Id. at 53 .

208. Id. at 53, n.9. Three justices in Ritchie rejected the plurality's view "that the Confrontation Clause protects only a defendant's trial rights and has no relevance to pretrial discovery." Id. at 61 (Blackmun, J., concurring in part and concurring in the judgment); see also id. at 66 (Brennan and Marshall, JJ., dissenting). In their view, "the right of cross-examination also may be significantly infringed by events occurring outside the trial itself, such as the wholesale denial of access to material that would serve as the basis for a significant line of inquiry at trial." Id.

209. Wardius v. Oregon, 412 U.S. 470,475 (1973).

210. Id. at 471-72.

211. Id. at 476 ("It is fundamentally unfair to require a defendant to divulge the details of his own case while at the same time subjecting him to the hazard of surprise concerning refutation of the very pieces of evidence which he disclosed to the State"). 
reciprocity, however, does not affirmatively require a state to adopt rules allowing discovery from the prosecution. ${ }^{212}$

The Supreme Court cases relating to discovery pose some obstacles to this article's claim that the Right to Counsel Clause is the appropriate framework for an analysis of certain pretrial discovery claims. First, the Court has demonstrated a rather singular focus on the Due Process Clause for analyzing access-to-information claims. Second, the cases impose a high burden through the materiality requirement. Third, their general language indicates an unwillingness to analyze non-Brady discovery claims in a constitutional framework. The Court's access-to-information cases, however, fail to examine the critical link between restrictions on discovery and defense counsel's constitutional duty to investigate. They also pre-date the Court's recent Wiggins decision which gives new meaning to that duty. ${ }^{213}$.

One Supreme Court case that addresses the duty to investigate and the right to effective assistance of counsel does recognize the significance of discovery. In Kimmelman v. Morrison, ${ }^{214}$ trial counsel "neither investigated, nor made a reasonable decision not to investigate, the State's case through discovery."215 Morrison's attorney's failure to request discovery was apparently driven by his mistaken belief that the state had an obligation to inform him of its case against his client-including the fact that law enforcement had seized property from his client's home. Because of the failure, counsel never filed a motion to suppress the physical evidence. ${ }^{216}$ The Court found that counsel's performance was constitutionally deficient under the first prong of Strickland's ineffective assistance of counsel test. ${ }^{217}$ The failure to investigate the merits of the sup-

212. Id. at 477-78.

213. See supra Part I.B (discussing Wiggins and the duty to investigate).

214. 477 U.S. 365 (1986).

215. Id. at 385 .

216. Id. at 368-69. Counsel also claimed that he did not seek discovery because he had information that the complaining witness did not wish to go forward with the case and he thought this meant that the case would not go to trial. Id. at 369 .

217. Id. at 386. The Supreme Court first rejected the government's claim that the restrictions on federal habeas review of Fourth Amendment issues announced in Stone v. Powell should extend to Sixth Amendment ineffective assistance claims if those claims relate to the failure to appropriately litigate Fourth Amendment issues. Id. at 373-83. After finding deficient performance, the Court remanded the case for a determination with respect to the requirement that the defendant demonstrate that counsel's deficient performance caused prejudice. Id. at 390-91. On remand, the district court granted habeas relief and ordered a new trial. Morrison v. Kimmelman, 650 F. Supp. 801, 809-10 (D.N.J. 1986) (concluding that "the defense attorney's errors dramatically affected the evidentiary picture in this case" and that "it is a least "rea- 
pression issue was inexcusable because it was caused by the "total failure to conduct pre-trial discovery." 218 This was true even though defense counsel's trial performance was "generally creditable enough." 219 Under Kimmelman, counsel's failure to seek discovery was deficient performance because discovery was necessary to ensure the ability to investigate. Although the case examines defense counsel's failure to seek discovery, externally-imposed restrictive discovery rules result in the same deficient performance: the inability to investigate. Surely the government cannot cause by rule the very result that the Court in Kimmelman condemned.

In Kimmelman, the Court unambiguously understood the need for discovery in order to undertake investigation into the case. It also implicitly recognized that the client cannot be expected to provide all the information necessary for counsel's investigation. Even though the government seized a sheet from Morrison's bed, and even though a neighbor let the police into Morrison's apartment, the Court noted, without challenging, defense counsel's assertion that "he had not heard of the seizure until the day before, when trial began, and that his client could not have known of it because the police had not left a receipt for the sheet." 220 The assumption is that discovery of the relevant information in a timely enough fashion would have alerted defense counsel to the need to undertake the necessary investigation.

In Strickland, the Court also made the baseline assumption that investigation must be based at least in part on access to information from the prosecution. In articulating the constitutional standard for the duty to investigate, the Supreme Court adopted the Court of Appeals' framework of informed strategic decision-making. ${ }^{221}$ The Fifth Circuit opinion assumed that counsel will, at a bare minimum, consult with his client and review the state's caseby examining the state's evidence-before deciding upon a strategy. ${ }^{222}$ The Supreme Court decision, similarly, described how limits upon "time and money" can force early strategic decisions that

sonably probable' that but for the attorney's errors, the balance would have tilted in favor of Morrison's version, and that he would have been acquitted").

218. Kimmelman, 477 U.S. at 386.

219. $I d$.

220. Id. at 369.

221. Strickland v. Washington, 466 U.S. 668, 690-91 (1984) ("As the Court of Appeals concluded, strategic choices made after thorough investigation of law and facts relevant to plausible options are virtually unchallengeable; and strategic choices made after less than complete investigation are reasonable precisely to the extent that reasonable professional judgments support the limitations on investigation").

222. Washington v. Strickland, 693 F.2d 1243, 1254 (5th Cir. 1982). 
may be based only on client consultation "and a review of the prosecution's evidence."223 These acknowledgements are significant because they assume that defense counsel has access to the prosecution's evidence before making strategic decisions; in other words, they assume that the defendant has some modicum of discovery. ${ }^{224}$

The absence of Supreme Court case law on the Right to Counsel Clause in the Court's discovery jurisprudence could make the argument for a fresh look at discovery through such a lens a hard sell in some quarters. But courts are becoming increasingly sensitive to effective assistance claims, at least in death penalty cases. This awareness should filter down to non-capital cases where the same concerns about the need for effective assistance, the potential for wrongful conviction without it, and general fairness in the administration of criminal justice equally apply. If the duty to investigate is to have the meaning that Wiggins seems to give it, ${ }^{225}$ defense counsel must have the tools she needs to investigate early in the process. A right-to-counsel analysis of restrictive discovery is squarely presented in the wake of Wiggins. If Wiggins signals that "what was once a boilerplate ground for appeal has gained new bounce," 226 then the courts can no longer ignore the relationship between discovery, investigation, and the right to effective assistance of counsel.

The next Part considers the major arguments against broad discovery and demonstrates that they are either outdated, insignificant, or can be addressed within a system of broad discovery.

\section{The Debate Over Liberal Discovery Rules}

Arguments against broad discovery lack current validity. The main purpose of pretrial discovery in criminal cases is to further the overarching purpose of the criminal justice system: the search for truth. ${ }^{227}$ The same reasoning is found in the cases defining the right to counsel as the right to effective assistance of counsel: "The

223. Strickland, 466 U.S. at 681.

224. One could argue that by "a review of the prosecution's evidence," the Strickland Court meant nothing more than an examination of the charging instrument. Id. But surely such review allows for more than the paltry amount of information contained in a typical indictment or complaint.

225. See supra Part I.B (discussing Wiggins and the duty to investigate).

226. John Council \& Tony Mauro, 'Wiggins' Get Lower Courts' Notice, Nat'L L.J., Feb. 9, 2004, at 6 .

227. See 1990 Brennan, supra note 5 , at 2 (stating that "[t]he essential purpose of permitting a criminal defendant to engage in pretrial discovery of the prosecution's case is to enhance the truth-finding process so as to minimize the danger that an innocent defendant will be convicted"); see also United States v. Cronic, 466 U.S. 648, 
very premise of our adversary system of criminal justice is that partisan advocacy on both sides of a case will best promote the ultimate objective that the guilty be convicted and the innocent go free."228 This could be called the fairness, or the justice rationale, for discovery.

There are other, more practical reasons for discovery, as outlined in a prosecutor's amicus brief filed in support of a defendant's request for broader discovery rights:

Under the present system in civilized communities where counsel is informed of the real strength of the Commonwealth's case, he is better enabled to give the proper advice to his client and trials are shortened, issues are met more fairly, guilty pleas are very often made, particularly in homicide cases, and the administration of justice is not only speeded up but made more fair and exact. ${ }^{229}$

The state interest in shorter trials or quicker pleas might be called the efficiency rationale for discovery. It is the primary impetus behind many prosecutors' support of broad discovery. ${ }^{230}$

A third rationale for broad discovery is that it ameliorates the resource imbalance between state and defendant. Justice Brennan, after noting a systemic interest in evenly-balanced scales in the contest between often indigent defendants and the state, posits discovery as "one tool whereby [defendants] would have a better chance to meet on more equal terms what the state, at its leisure and without real concern for expense, gathers to convict them."231

Discovery was not always recognized as an important tool in advancing these goals. Drawing upon English precedent prohibiting pretrial discovery, ${ }^{232}$ the early American common-law rule was that

655-56 (1984) (fairness in the adversary process gives meaning to the Sixth Amendment right to effective assistance of counsel).

228. Herring v. New York, 422 U.S. 853, 862 (1975). Justice Brennan, in describing the latter half of this goal, has called it the "superlatively important public interest in the acquittal of the innocent." 1963 Brennan, supra note 5, at 287.

229. 1963 Brennan, supra note 5, at 283 n.10 (quoting Di Joseph Petition, 145 A.2d 187 (Pa. 1958)).

230. See Traynor, supra note 5, at 237 (noting how some federal prosecutors voluntarily disclose information to defense counsel to both expedite trials and also because such disclosure "in some cases has convinced the defense of the strength of the prosecution's case and thereby induced a plea of guilty" (citation omitted)); see also 1990 Brennan, supra note 5, at 2 (remarking that the essential purpose of discovery is to advance truth-seeking goal but plea bargaining is the main impetus for discovery).

231. 1963 Brennan, supra note 5, at 286 (citations omitted).

232. See Rex v. Holland, 100 Eng. Rep. 1248 (K.B. 1792) (finding that defendant's pretrial request to inspect a report of witness accounts was without principle and precedent and that to grant it "would subvert the whole system of criminal law"). The 
courts did not have the inherent authority to order such discovery in criminal cases. ${ }^{233}$ By the late 1940s, a majority of states allowed pretrial discovery. ${ }^{234}$ At the same time, the liberalization of civil discovery took place, resulting in each side getting full pretrial access to the other side's information. ${ }^{235}$ While the success of the civil discovery experiment led to calls for broader discovery in the criminal arena, ${ }^{236}$ opposition to such a parallel liberalization was substantial. ${ }^{237}$ Thus, during the 1950 s and 1960s "there occurred . . .one of the classic debates in the field of criminal procedure."238 While most states have significantly broadened pretrial

Holland court noted that the practice was instead to allow inspection of the evidence at "the hour of trial." Id. at 1250 . With respect to witness statements, New York follows the practice as it was in 1792: the right to discover statements of trial witnesses attaches only after the jury is sworn. N.Y. CRIM. Proc. Law $\$ 240.45$ (McKinney 2002); see also supra notes $124 \& 146$ and accompanying text (discussing New York law on discovery of witness statements). Professor Wigmore later questioned the American courts' characterization of the English rule as absolute, taking the position that the prohibition was a rule of policy rather than power. Many states came to accept this position, which resulted in recognition of the trial court's power to order pretrial discovery as an exercise of its inherent authority to control the trial process. See 3 Wigmore, Evidence, $\$ \S 1859 \mathrm{~g}, 1863$ (cited in People ex rel Lemon v. Supreme Court, 245 N.Y. 24, 31 (1927)); LAFAVE, supra note 8, § 20.1, at 910-11.

233. See, e.g., People ex rel Lemon v. Supreme Court, 156 N.E. 84, 84-86 (N.Y. 1927) (Cardozo, J.) (detailing English common law prohibition on pretrial discovery and application of that rule in American courts); see also Michael Moore, Criminal Discovery, 19 HASTINGS L.J. 865, 866 (1968) ("American courts readily picked up the doctrine of Rex $v$. Holland, to the effect that they were without power, absent legislation, to order the prosecutor to divulge evidence which he had in his possession"). But see Trial Manual 5, supra note $16, \S 265$ (noting that the frequent observation that the common law allowed no discovery "is not strictly accurate," as the courts had-at least since United States v. Burr, 25 Fed. Cas. 30 (No. 14,692d) (C.C.D. Va. 1807 - discretionary power to compel production of materials, although this "power was seldom used before the second half of the twentieth century" and was even denied in some recent decisions).

234. See LAFAVE, supra note 8 , § 20.1, at 910.

235. See, e.g., Fed. R. Civ. Proc. 26; LAFAve, supra note 8, § 20.1, at 910.

236. Lemon, 156 N.E. at 86 (noting, in describing call for application of civil case rules of evidence to criminal cases: "The appropriation is justified, we are told, by the germinal developments of a like power in the courts of other States, by the public policy implicit in the rule of uniformity of evidence ... and by the necessities of justice").

237. 1963 Brennan, supra note 5 , at 283 (listing several states as having "made strides" in the liberalization of pretrial discovery in criminal cases but noting that "by and large the states are still unreceptive"); id. at 288 (stating that "rigid opposition to pretrial criminal discovery for the accused still persists").

238. LAFAVE, supra note $8, \S 20.1$, at 911 . The crux of the debate is captured in a seminal lecture published in 1963 called, The Criminal Prosecution: Sporting Event Or Quest For Truth?. See 1963 Brennan, supra note 5. Justice Brennan poses the question: "Should we extend to criminal prosecutions the civil pretrial discovery techniques which force both sides of a civil law suit to put all cards on the table before trial, and tend to reduce the chance that surprise or maneuver, rather than truth, may 
discovery in criminal cases since this debate, ${ }^{239}$ the arguments on both sides are very much alive in jurisdictions that have resisted liberalization. The sections below will describe the three main arguments against discovery, and address why these arguments are largely without merit. ${ }^{240}$

\section{A. The Witness Interference Argument}

The most common argument against broad discovery is that allowing the defendant access to information about witnesses will lead to interference with those witnesses. The claim is that the defendant will try to convince potential prosecution witnesses to either change their testimony or not testify at all, by bribing, threatening, physically injuring, or even killing them. ${ }^{241}$ A more

determine the outcome of the trial?" Id. at 279. In answering this question affirmatively (although not based on constitutional considerations), Justice Brennan described and then pointed out flaws in the major arguments against broader discovery. Id. at 289-293. The New Jersey Supreme Court articulated these arguments in State $v$. Tune, a decision in which Justice Brennan-then sitting on that court-was in the minority. See State v. Tune, 98 A.2d 881, 884 (N.J. 1953). For other commentary and case law surrounding the debate, see generally Traynor, supra note 5, at 249 ("Valuable though discovery has proved in clarifying issues and expediting their trial, it has yet to overcome the usual resistance of those who are set in old ways"). See also United States v. Garsson, 291 F. 646, 649 (S.D.N.Y. 1923) (containing Learned Hand's condemnation of discovery in criminal cases); Abraham S. Goldstein, The State \& the Accused: Balance of Advantage in Criminal Procedure, 69 Y ALE L. J. 1149 (1960); David W. Louisell, Criminal Discovery: Dilemma Real or Apparent?, 49 CAL. L. REV. 56 (1961).

239. See supra notes 5-10 \& 119-127 and accompanying text (giving overview of spectrum of discovery rules currently in place in the United States); see also Milton C. Lee, Criminal Discovery: What Truth Do We Seek?, 4 U.D.C. L. REv. 7, 8 (1998) [hereinafter Lee, What Truth?] (noting that approximately thirty-seven states have discovery statutes that are more progressive than the restrictive federal model); Traynor, supra note 5, at 229 (writing in 1964 and noting that "the trend is toward liberalizing discovery").

240. The Tune court actually described four arguments against discovery. Id. The fourth is that the positive experience the British have had with broader discovery is no model for our less law-abiding country. See 1963 Brennan, supra note 5, at 293 (describing argument that says: "the experience of other nations there broad discovery has not subverted the criminal law, notably England and Canada, does not help us" because we are a less law-abiding people and crime is increasing at a greater rate in this country than in those). This article does not address this point, as it was largely a response to defense counsel's argument in Tune and is generally not repeated in the discovery literature.

241. A commonly-cited source for this argument is a Justice Department representative's testimony, during the 1974-75 congressional hearings on proposals to amend the Federal Rules of Criminal Procedure, that disclosure of government witness names would be "dangerous and frightening in that government witnesses and their families will even be more exposed than they now are to threats, pressures, and physical harm." H.R. REP. No. 94-247, at 41 (1975), reprinted in 1975 U.S.C.C.A.N. 674, 
subtle, but much more compelling, argument is that of the potential chilling effect that mere knowledge of disclosure will have on witnesses; the claim is that this knowledge may prevent witnesses from cooperating with the prosecution or even from coming forward in the first instance. ${ }^{242}$

This argument is flawed, however, in its assumption that restrictive discovery is the only-or the best-way to prevent witness interference. For example, in the great majority of drug cases, which make up more than one-third of federal prosecutions, there are no civilian witnesses. ${ }^{243}$ With a very few exceptions, police officers and other government officials do not need protection against intimidation or the chilling effect. ${ }^{244}$ When necessary, there are ways to protect against intimidation or the chilling of non-governmental witnesses within a system of broad discovery. A protective order blocking the identity of a particular witness, based on a showing that such protection is necessary, is a device already used in both civil and criminal practice. ${ }^{245}$ Another approach would disclose the

712. During subcommittee hearings, prosecutors "cited and documented hundreds of instances in virtually every judicial district in the United States where, under existing Rules, government witnesses are murdered, threatened or suborned to commit perjury." Id.; see also supra note 126 (describing proposed amendments to federal discovery rules).

242. See, e.g., H.R. Rep. No. 94-247, at 41; William Glaberson, Man Acquitted of a Murder in Brooklyn: Case Raised Allegations of Witness Intimidation, N.Y. TimEs, Dec. 6, 2003, at B1 (describing case "that highlighted the dangers of witness intimidation and New Yorkers' often unspoken fears about cooperating with law enforcement officials").

243. In the period from Oct. 1,2000 to Sept. $30,2001,36.7 \%$ of the cases prosecuted in the United States District Courts were drug related. Bureau of JUSTICE Statistics, U.S. Dep't of Justice, Federal Criminal Case Processing, 2001, at 10 (2003), available at http://www.ojp.usdoj.gov/bjs/abstract/fccp01.htm. While there might be civilian confidential informants in some drug cases, the government can seek a protective order where necessary.

244. Undercover agents might be an exception although for reasons other than a chilling effect, such as not blowing their cover. There might also be concern in largescale drug cases, or drug cases that also involve charges of a violent crime, but these will be a small minority of drug cases and can be dealt with by protective order.

245. See, e.g., Fed. R. CIV. P. 26(c) (allowing for protective orders in civil case discovery); N.Y. CrIM. Proc. Law $\$ 240.50$ (McKinney 2002) (allowing for protective orders in discovery process in criminal cases); see also Louisell, supra note 238, at 100 (suggesting that discovery law "draw the line between typical, and organized, crime" and proposing that "[i]n the usual criminal case, the norm would be discovery as fullfledged as that which now characterizes civil litigation" but restricting or even withholding discovery in cases where the prosecution has made an appropriate showing of need based on the "nature of the accused's associations and representatives"); Traynor, supra note 5, at 250 ("If the prosecution has assurance of secrecy upon a showing of circumstances to justify it, there would be little objection to full pretrial disclosure to the defense when there is no reasonable basis for secrecy"). 
information to defense counsel without disclosing it to the defendant and prohibit defense counsel from doing so. ${ }^{246}$

Further, "[ $\mathrm{t}]$ he concerns regarding witness intimidation . . . have been refuted by the experience of the states." 247 In Florida, a state with broad discovery that allows for depositions of certain prosecution witnesses, the state Supreme Court commissioned a study which recognized infrequent, yet serious cases, of witness intimidation but noted that both public defenders and prosecutors agreed that this was not the result of the broader discovery process. ${ }^{248}$ The Commission recommended retaining a defendant's right to depose government witnesses. ${ }^{249}$ Another study found that, in four cities with broad discovery rules, there was no causal link between open discovery and witness intimidation. ${ }^{250}$ In short, "the proper response to the intimidation problem cannot be to prevent discovery altogether; it is rather to regulate discovery in those cases in which it is thought that witness intimidation is a real possibility."251

The potential for a chilling effect is harder to cure even with the availability of protective orders and other such measures. As noted above, however, broad discovery states have not felt the need to revert back to a more restrictive rule. A chilling effect is also inherent in criminal cases in ways unrelated to discovery, because the witness may have to testify in the grand jury, at a pretrial hearing, or at trial. Whether the defendant has access to witness information is unlikely to add considerably to this burden. Absent

246. See Lee, What Truth?, supra note 239, at 25 ("The Florida experience [with broad discovery] suggests that witness intimidation can be minimized by disclosing information to the attorney without disclosing it to the accused"). While this approach can pose problems with respect to the attorney-client relationship, it could be a last-resort tactic preferable to denial of discovery.

247. Id. at 23.

248. Id. (describing Florida Supreme Court's 1988 Commission on Criminal Discovery report).

249. Id.

250. See W.M. Bradford Middlekauff, What Practioners Say About Broad Criminal Discovery Practice, CRIM. Jusr. Spring 1994, at 14, 58, stating that:

In some cities with broad discovery practice, such as San Diego, Philadelphia, Detroit, and Newark, prosecutors saw no significant causal link between discovery and witness intimidation. In Los Angeles and Chicago, on the other hand, prosecutors acknowledged that there might be some link between discovery and witness intimidation but noted that there were sufficient methods available to protect witnesses. Even in these cities, there was not a strong view that currently [sic] broad disclosure rules should be made more limited.

251. 1990 Brennan, supra note 5, at 14; see also People v. Andre, 375 N.E.2d 758, 762 (N.Y. 1978) (noting "[t]he availability of a legal arsenal of protection" should there be legitimate concern regarding witness intimidation). 
a particularized showing, this concern should not be allowed to trump a defendant's right to effective assistance of counsel.

\section{B. The Perjury Argument}

Some have argued that a defendant accorded broad discovery will use his knowledge of the prosecution's case to fashion perjured testimony. The claim is that the defendant will tailor his own testimony to ensure minimal conflict with the prosecution's case and construct an entire defense that refutes the prosecutor's evidence. This same justification was used historically to deny a defendant the right to produce any witnesses at all. ${ }^{252}$ It assumes the defendant is guilty and is willing to commit another crime to be acquitted. It also assumes that defense counsel will conspire with the defendant to commit the perjury. ${ }^{253}$ The denial of discovery does not solve the problem-if there is one-because the defendant sits through the prosecution case before he or any witnesses he chooses to call would testify which gives him ample opportunity to tailor testimony should he so choose. Similar concerns that were raised with respect to broader civil discovery proved unfounded and jurisdictions with broad criminal discovery have not found perjury to be a problem. ${ }^{254}$

\section{The Two-Way Street, or Reciprocity, Argument}

Opponents of broad pretrial discovery argue that it will give defendants an unfair advantage to give them prosecution material because the defendant's constitutional rights protect her from having to reciprocate. In United States v. Garsson, Judge Learned Hand stated:

Under our criminal procedure the accused has every advantage. While the prosecution is held rigidly to the charge, he need not disclose the barest outline of his defense. $\mathrm{He}$ is immune from question or comment on his silence; he cannot be convicted when there is the least fair doubt in the minds of any one of the twelve. Why in addition he should in advance have the whole

252. See 1963 Brennan, supra note 5, at 291; cf. Brooks v. Tennessee, 406 U.S. 605 , 612-13, 607 (1972) (finding state rule that a defendant must testify first or not at all unconstitutional, and noting that the concern behind such rules was defendant perjury).

253. 1963 Brennan, supra note 5, at 291-92.

254. See LAFAVE, supra note 8, § 20.1, at 912. 
evidence against him to pick over at his leisure, and make his defense, fairly or foully, I have never been able to see. ${ }^{255}$

First, this argument is to a great extent outdated, due to the passage of a number of statutes and court rules that require defendants to turn information over to the state. Alibi notice, which usually requires a list of alibi witnesses, is the most common example; ${ }^{256}$ some states go well beyond this and require defendants to share their full witness lists with the prosecution. ${ }^{257}$ Second, the government has a huge investigatory power advantage and it is highly unlikely that the vast majority of defendants can tactically overwhelm it. ${ }^{258}$ In striking down a state law requiring defendants to give notice of alibi without requiring reciprocal discovery from the government, the Supreme Court noted that "the State's inherent information-gathering advantages suggest that if there is to be any imbalance in discovery rights, it should work in the defendant's favor." $" 259$

In sum, the Sixth Amendment right to the effective assistance of counsel requires broad discovery, and there is no strong practical argument against it.

\section{Conchusion}

There is perhaps no function of defense counsel more critical than investigation of the prosecution's case and of possible defenses. The vast majority of cases never go to trial, so while coun-

255. United States v. Garsson, 291 F. 646, 649 (D.C.N.Y. 1923) (denying defendant's motion to inspect the grand jury minutes and commenting that "[o]ur procedure has been always haunted by the ghost of the innocent man convicted. It is an unreal dream").

256. See, e.g., Williams v. Florida, 399 U.S. 78, 83 (1970) (upholding constitutionality of notice-of-alibi rules applied to defendant); see also supra notes 183-189 and accompanying text.

257. See, e.g., ILL. SuP. CT. R. 413(d) (West 2004) which requires:

Subject to constitutional limitations and within a reasonable time after the filing of a written motion by the State, defense counsel shall inform the State of any defenses which he intends to make at a hearing or trial and shall furnish the State with the following material and information within his possession or control: ... . (i) the names and last known addresses of persons he intends to call as witnesses, together with their relevant written or recorded statements, including memoranda reporting or summarizing their oral statements, [and] any record of prior criminal convictions known to him.

258. See Traynor, supra note 5, at 229 (stating that "the protection afforded the defendant against discovery is in large measure counterbalanced by the abundant resources for investigation available to the prosecution").

259. Wardius v. Oregon, 412 U.S. 470,476 n.9 (1973). But see id. at 480 (Douglas, J., dissenting) ("Much of the Bill of Rights is designed to redress the advantage that inheres in a government prosecution. It is not for the Court to change that balance"). 
sel's performance in the courtroom is certainly important, it is counsel's performance in the preparation of cases-leading up to the much more likely result of a plea bargain-that really matters. ${ }^{260}$ Yet in addressing inadequate investigation, courts and commentators have failed to ask a critical question: does defense counsel have the tools that she needs in order to fulfill her Sixth Amendment duty to investigate? If we truly value the presumption of innocence and we recognize the reality that many defendants are not equipped to provide their attorneys with the information needed for an effective investigation, then the role of discovery in the investigatory process is clear. The highly restrictive discovery that exists in a significant number of jurisdictions constitutes government interference with the effective assistance of counsel.

Recognizing that restrictive discovery can lead to a violation of the Sixth Amendment raises at least two important issues. First is a question of institutional competence: should the legislature or the courts change constitutionally defective discovery rules? ${ }^{261}$ Second, assuming that a court is faced with a defendant's claim of a Sixth Amendment violation due to restrictive discovery, how might that court analyze such a claim? It is beyond the scope of this article to explore fully the various remedies that might resolve the Sixth Amendment infirmities of a restrictive discovery rule. A rule of open file discovery, however, in which the prosecution literally opens its file for inspection by defense counsel (with the exception of work product and subject to the ability to seek protective orders) would cure the unconstitutionality of any governmentally-im-

260. See supra notes 178-181 and accompanying text (discussing the importance of discovery in the plea bargain context).

261. At first blush, it appears that the legislature is the institution best suited to write discovery rules. It has the relevant expertise, for example, to consider the economic consequences of different potential discovery rules and to consider the rules in light of the whole body of Criminal Procedure Law. Unfortunately, legislatures do not always act to protect constitutional rights, and certainly do not always do so when those in need of protection are defendants in criminal cases-a group lacking in political power. See Alec C. Ewald, Civil Death: Ideological Paradox of Criminal Disenfranchisement Law in the United States, 2002 WIS. L. REv. 1045, 1054 n.23 (2002) (noting that all but two states have some type of disenfranchisement law, ranging from loss of the vote during incarceration only to indefinite loss of the right for some offenders); see also Donald Dripps, Criminal Procedure, Footnote Four, and the Theory of Public Choice, 44 SyRaCUSE L. REv. 1079, 1081 (1993) (using public choice theory to consider the failure of legislatures to protect constitutional criminal rights). At the very least, a court that grants a defendant's Sixth Amendment challenge to a discovery statute will of necessity be the institution to consider the appropriate remedy for that violation, at least with respect to that one case before the court. 
posed discovery obstacle to the ability to investigate. ${ }^{262}$ The remedy of open file discovery would be prophylactic, in the sense that it would be a "risk-avoidance rule[ ] . . . not directly sanctioned or required by the Constitution, but . . . adopted to ensure that the government follows constitutionally sanctioned or required rules." 263 As such, it would be consistent with other rules of criminal procedure: "Constitutional criminal procedure is rife with prophylactic rules."264

A rule of open file discovery would have the great benefit of avoiding an unworkable system of case-by-case inquiry into individual restrictive discovery claims, a method that is likely to lead to underenforcement of the right to effective assistance. ${ }^{265}$ In addition, the costs of open file discovery are very low. As discussed in Part III, the three major arguments historically advanced in opposition to broader discovery rules lack validity. While there may be administrative costs to open file discovery, since such a rule will lead to more discovery generally and to discovery in cases with early plea bargains in which it may not have otherwise occurred, there will be a corresponding savings in the probability that pleas will happen earlier if the defendant has an opportunity to view the

262. It would cure the problem in the sense of removing the unconstitutionally restrictive rule. Still, even under a rule of open file discovery the ability to adequately investigate would turn in part on the extent to which the prosecution exercised diligence and good faith in seeking out information early in the case, and in turning over later information as it is acquired. See generally Strickler v. Greene, 527 U.S. 263, 275 (1999) (despite open file policy of prosecutor, defense counsel never received exculpatory evidence because the critical documents "were not in the file [the prosecutor] made available to petitioner" and the prosecuting attorney "never saw" the documents "until long after" the trial). While a full discussion of the issues surrounding open file discovery is beyond the scope of this article, with proper safeguards such a rule would lift impediments to the right to effective assistance of counsel.

263. Brian K. Landsberg, Safeguarding Constitutional Rights: Uses and Limits of Prophylactic Rules, 66 TENN. L. REv. 925, 926 (1999) (stating that prophylactic rules "are directed against the risk of noncompliance with a constitutional norm").

264. See Susan R. Klein, Identifying and (Re)Formulation Prophylactic Rules, Safe Harbors, \& Incidental Rights in Constitutional Criminal Procedure, 99 MiCH. L. Rev. 1030, 1037 (2001); see also Evan H. Caminker, Miranda and Some Puzzles of "Prophylactic" Rules, 70 U. CiN. L. REV. 1, 1 (2001) (arguing that there is no real difference between such rules and "run-of-the-mill judicial doctrines routinely constructed by the Court that we unquestionably accept as perfectly legitimate exercises of judicial power").

265. The Supreme Court recently affirmed its rejection of the case-by-case inquiry as the sole method for evaluating the voluntariness of custodial confessions. In Dickerson v. United States, the Court noted that its abandonment of the traditional caseby-case inquiry into the totality of the circumstances surrounding a confession in favor of the prophylactic Miranda warning rule was necessary to avoid a "risk of overlooking an involuntary custodial confession ... that the Court found unacceptably great ...." 530 U.S. 428, 442 (2000) (internal citations omitted). 
government's evidence. ${ }^{266}$ In short, the high benefits and low costs to the prophylactic rule of open file discovery make such a remedy particularly appropriate to cure Sixth Amendment violations resulting from restrictive discovery.

Restrictive discovery claims should be analyzed in light of a defendant's Sixth Amendment right to the effective assistance of counsel. With broad discovery, in the form of a rule that gives counsel the tools they need to adequately investigate their cases, the Jane Smiths of our criminal justice system would not have to suffer the injustice of spending two years in prison for a criminal act they did not commit. accompanying text. 